\title{
Preconceptions of the Samarra Horizon, Green Splashed Ware and Blue Painted Ware Revisited through Chinese Ceramic Imports (Eighth to Tenth Centuries)
}

\author{
Wen Wen | ORCID: 0000-0001-5414-7022 \\ Independent researcher \\ wenwencrystal@gmail.com
}

\begin{abstract}
This paper brings in new and not-well-known archaeological evidence to the debate over the Samarra Horizon, and reviews some preconceptions of the green splashed ware and blue painted ware through Chinese ceramic imports found in several sites in the Middle East from the eighth to tenth centuries $\mathrm{CE}$. There has been mutual influence between Islamic and Chinese ceramics in the early Abbasid period, and there may be more than one explanation for their visual similarities.
\end{abstract}

Keywords

Samarra Horizon - Ceramic - Abbasid - Chinese - Islamic - Middle East

1

Background

Discussions of the Samarra Horizon and Chinese ceramic imports were initiated by excavations in Samarra from 1910 to 1913. Samarra was founded as the capital and residence of Abbasid caliphs in $836 \mathrm{CE}$. The city declined after the caliph al-Mu'tadid (r. 892-902 CE) returned to Baghdad in $892 \mathrm{CE}$. Chinese and Islamic ceramics of various types were found from the excavations, the majority of which could be dated to the ninth and early tenth centuries $\mathrm{CE}$. The eighth to tenth centuries $\mathrm{CE}$ witnessed the prosperity of the Abbasid caliphate ( $75^{-}-1258 \mathrm{CE}$ ) and the Chinese Tang Empire (618-907 CE) and the first peak of maritime exchange between the Islamic lands and China.

Arthur Lane (1909-63) considered the ninth-century Samarra glazed ceramics the beginning of fine Islamic pottery. He attributed the splendour of Samarra fine ceramics to the influence of techniques and artistic styles of imported Chinese ceramics (Lane, 1947: 10-11). The Samarra Horizon types of Islamic glazed ceramics refer to classic Iraqi Samarra wares, which comprise white glazed ware with and without decorations, and early lead glazed splashed ware with and without incised decorations (Northedge and Kennet, 1994: 21).

Over the last century, Chinese ceramics found in the Middle East and their connections with contemporary Islamic glazed ceramics have been studied by several generations of scholars. The significance of this topic still stands in the following ways. Firstly, the arrival of Chinese ceramics in the Abbasid caliphate from the eighth to tenth 
centuries CE formed a dynamic part of the material exchange across the Indian Ocean. It shows a geographic expansion of the scale of Indian Ocean maritime exchange whereby Chinese ceramics reached the Middle East. Secondly, it helps to gain more insight into the ceramic production in these two regions and possible exchange in materials, production techniques, ideas and artistic styles, rather than one-way influence and imitation only.

Among the Samarra Horizon types of Islamic glazed ceramics, there are white glazed ceramics imitating Chinese white ware which was also found in Samarra and other Islamic sites. The splashed ware genres including white ware with blue paintings, with green splashes, with multi-colour splashes or paintings have sparked considerable debate as to whether they were imitations of Chinese classic Tang Sancai ware or Chinese green splashed ware and blue painted ware.

Recently, Watson raised awareness of the danger of over-simplifying the explanation of the Samarra Horizon by attributing it entirely to the influence of Chinese wares (Watson, 2014: 123-42). The relationship between them was not a simple, one-way influence of one on the other. There were mutual interactions which involved not only ceramics, but also other materials exchanged between these two cultures. Many ideas generated a long time ago are still widely adopted without being examined against new materials and research from the Islamic world and China.

\section{2}

\section{Chinese Splashed Ware and Blue Painted Ware Found in the Islamic Middle East (Eighth to Tenth Centuries CE)}

Among the 167 Islamic sites dating to the eighth to tenth centuries CE studied in the author's DPhil research, only sixteen of them have yielded Chinese splashed ware and blue painted ware finds (Fig. 1) (Wen, 2018: 26). These include four city-level settlements, Samarra, Fustat, Sirjan and Nishapur (red dots); two important port sites, Siraf and Sohar (yellow dots); one town-level settlement, Shahr-i-daqianus, and one pilgrimage route station, Zubalah (blue dots). The rest are village-level settlements (green dots) and small ports (yellow dots) in the Persian Gulf on the Iranian side. The amount of these two types of Chinese wares found in these sites is scarce.

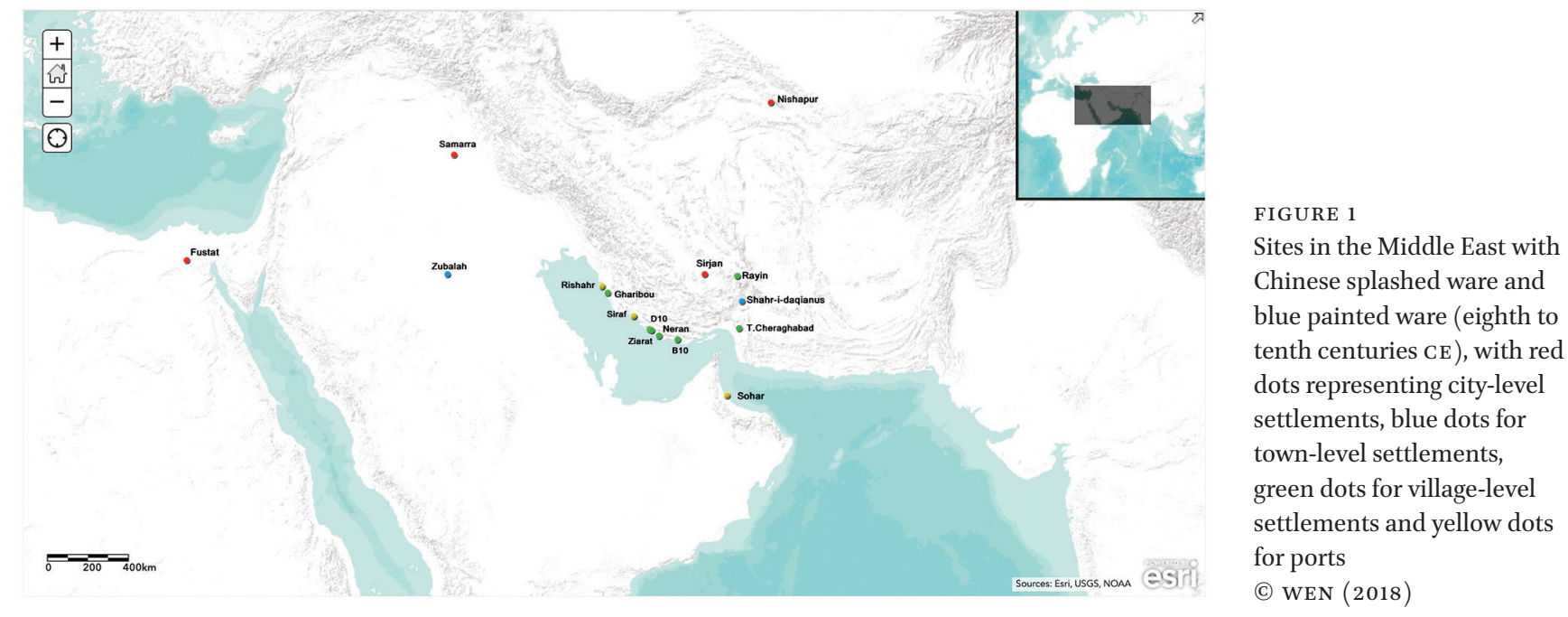




\section{Is There Classic Tang Sancai Ware Found in Islamic Sites (Eighth to Tenth} Centuries CE)?

Classic Tang Sancai ware (Fig. 2) was produced in China primarily between the seventh and tenth centuries CE with glaze or slip normally in three colours, though sometimes in only one colour or two or more than three colours. There have always been questions as to whether classic Tang Sancai ware ever arrived in the Islamic lands during the early Abbasid period, thus exerting influence on the Samarra Horizon splashed ware.

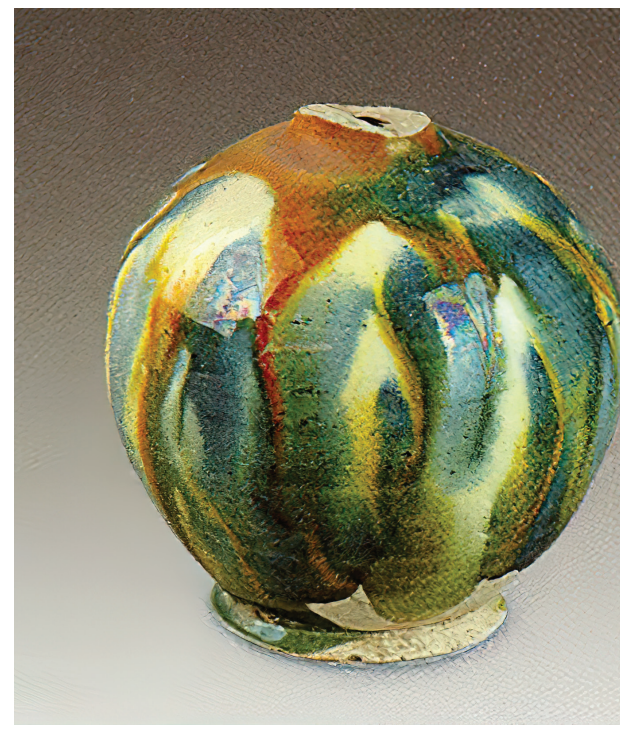

\subsection{Nishapur}

A so-called Sancai ware sherd with bluish green, purple and yellow splashes was reported to be found in Nishapur. Wilkinson described the body of this sherd as made of kaolin and fired to a higher temperature, which made it almost vitrified (Wilkinson, 1973: 256). Thus, Wilkinson identified it as Chinese stoneware rather than an Islamic one, which was normally low-fired pottery. This sherd (Fig. 3 ) is only published in black and white in Wilkinson (1973: 257) as Chinese sherd no. 9. Without a detailed analysis, it is too early to assume this sherd came from a Chinese ware. A proper examination would help shed light on whether this sherd came from classic Tang Sancai ware or other types of Chinese splashed ware.

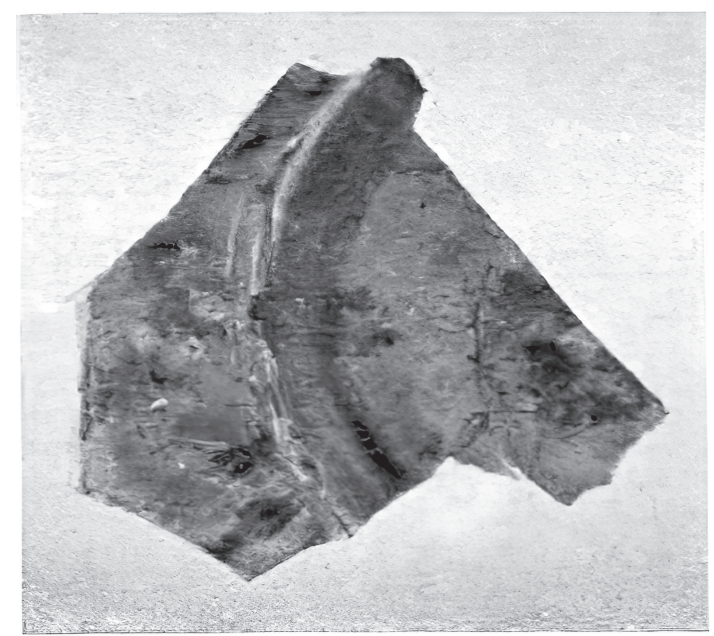

FIGURE 3

Chinese sherd no. 9 excavated from Nishapur

(C) WILKINSON (1973: 258) 


\section{2 $\quad$ Fustat}

Sancai sherds are alleged to have been found in the excavations of Fustat over the last century. Gyllensvärd categorised these alleged Tang Sancai ware sherds excavated by the American archaeological missions led by Scanlon as Liao Sancai (Gyllensvärd, 1973: 92). Liao Sancai ware, produced from the late tenth to early twelfth centuries $\mathrm{CE}$, shares much in common with Tang Sancai ware; both are normally low fired and polychrome painted. Although Liao Sancai ware may have been found in Fustat, it was produced later than the ninth century $\mathrm{CE}$, thus could not possibly have exerted influence on the ninth-century Samarra Horizon splashed ware.

Scanlon mentioned a turquoise-coloured bowl with white stoneware body and carved leaf swirl decorations (Fig. 4), which he believed was Liao Sancai ware and dated it to the early eleventh century CE (Scanlon and Kubiak, 1989: 49). However, these attributes do not belong to Liao Sancai ware. In fact, the carved leaf swirl recalls the decorations often seen on Chinese Yaozhou ware (耀州窑), and the turquoise glaze on a stoneware body is more an attribute of Islamic fritware.

Mikami examined ceramic finds from Fustat in Cairo and pointed out the existence of classic Tang Sancai ware. The Sancai sherds illustrated in his publication (Fig. 5a) are from the F.R. Martin Collection, the International Museum of Ceramics, Faenza, Italy (Mikami, 1982: 75). Even though Mikami described them as Fustat ceramic finds,

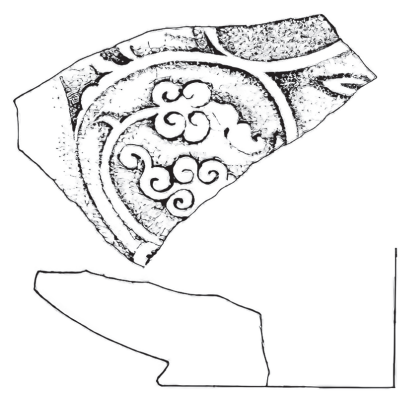

a

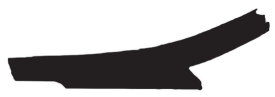

b
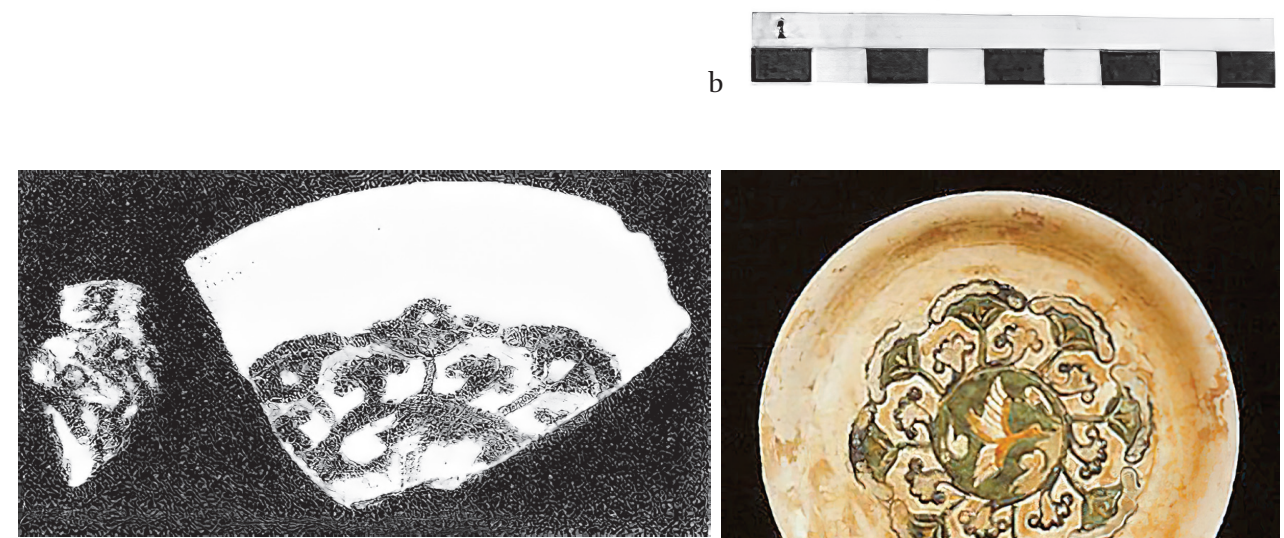

a

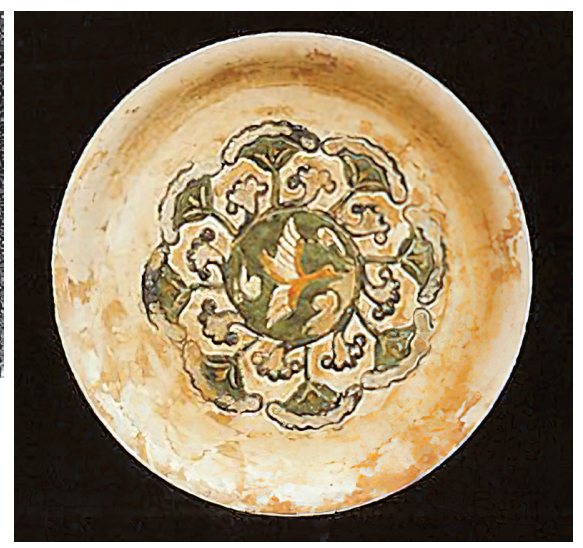

FIGURE 4

Turquoise glazed white stoneware sherd found in Fustat

(C) SCANLON AND KUBIAK

(1989: 49)
FIGURE 5

a. Two Sancai fragments attributed to Fustat; b. a Sancai tripod plate from the excavation of Huangye kilns

(C) A. MIKAMI (1982: 75);

B. GONGYI MUNICIPAL OFFICE FOR THE PRESERVATION OF ANCIENT MONUMENTS, HENAN PROVINCE (2000: PLATE 14) 


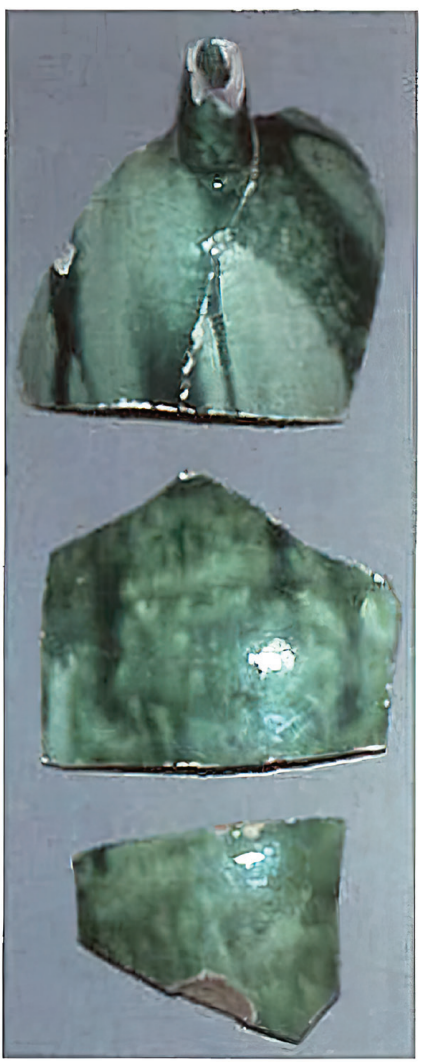

FIGURE 6

Chinese green splashed ware sherds from Fustat

(C) TADANORI (2013: 5) there is no solid archaeological evidence attributing these sherds to any excavation of Fustat. The smaller sherd seems to come from a green splashed ware with moulded relief decoration. The larger sherd has an incised floral motif in the middle on a white ground, which is a common type of decoration on classic Tang Sancai ware. However, classic Tang Sancai ware with similar decoration has not been found in any other site in the Islamic lands yet. In Mikami's original publication, the editor also added a note that there was no evidence these sherds were found in Fustat. In addition, Mikami also reported fragments of Tang Sancai bottles, bowls and dishes. Qin Dashu examined these ceramic finds in Cairo in the 199os and dated these Sancai bottle fragments to the late Liao period (late eleventh to early twelfth centuries CE). He concluded that there was no classic Tang Sancai ware among the ceramic finds of Fustat that he examined.

Tadanori surveyed ceramic finds of Fustat in Cairo in 1998 and found seven sherds of white glazed earthenware with green lead glazed splashes from Gongxian kilns (巩县窑) (Fig. 6) (Tadanori, 2013:4-5). There is no classic Tang Sancai ware identified in Tadanori's survey. Hobson mentioned in his publication in 1932 that "there are, for instance, pieces of buff stoneware with cream glaze mottled with green and brownish yellow, which came from China in the Tang dynasty" (Hobson, 1932: 109). Unfortunately, there are no illustrations or photos in his publication of the sherds mentioned above. It seems theses sherds mentioned by Hobson are more likely other types of Chinese splashed ware or Changsha ware (长沙窑) instead of classic Tang Sancai ware as pointed out by Gyllensvärd, Qin Dashu and Tadanori's respective surveys and research.

In fact, some scholars have already doubted whether classic Tang Sancai ware ever reached the Islamic lands. Medley observed that "Sancai ware" found in Islamic sites might not be the same type of classic Tang Sancai ware from elites' tombs during the High Tang period. "Chinese splashed ware found in the Islamic world had a less luxurious and more mundane appearance with a grey body, white slip and simple decoration, mostly florettes, executed in a more muted iron brown or copper green fritted glaze" (Medley, 1981: 87-8; Tampoe, 1989: 89). Rougeulle further noticed that almost all the so-called Sancai ware sherds found in Islamic sites are green splashed white ware (Rougeulle, 1991: 28). The author's DPhil research also concludes that only Chinese green splashed ware and one fragment of blue painted ware were found in sixteen sites among the 167 Islamic sites from the eighth to tenth centuries CE studied in the thesis (Fig. 1).

In summary, there is no firm evidence for any classic Tang Sancai ware found in the Abbasid lands so far. The Sancai ware sherds mentioned by Hobson, Mikami and Scanlon are either Liao Sancai ware or other types of Chinese wares. Therefore, the idea that classic Tang Sancai ware was exported to the Abbasid caliphate and imitated by Islamic splashed ware apparently lacks solid evidence unless new discoveries prove otherwise.

\section{Green Splashed Ware}

In fact, it is more precise to correlate Chinese green splashed ware with the Samarra Horizon Islamic splashed ware rather than the classic Tang Sancai ware. The production of Chinese green splashed ware started in the mid-to-late sixth century CE. These very early examples (Fig. 7) were all excavated from tombs which could be precisely dated by epitaphs and burial goods (Li Zhiyan, 1972: 53-4). The green stripes on these early examples seemed to have been applied in a rather random style. 

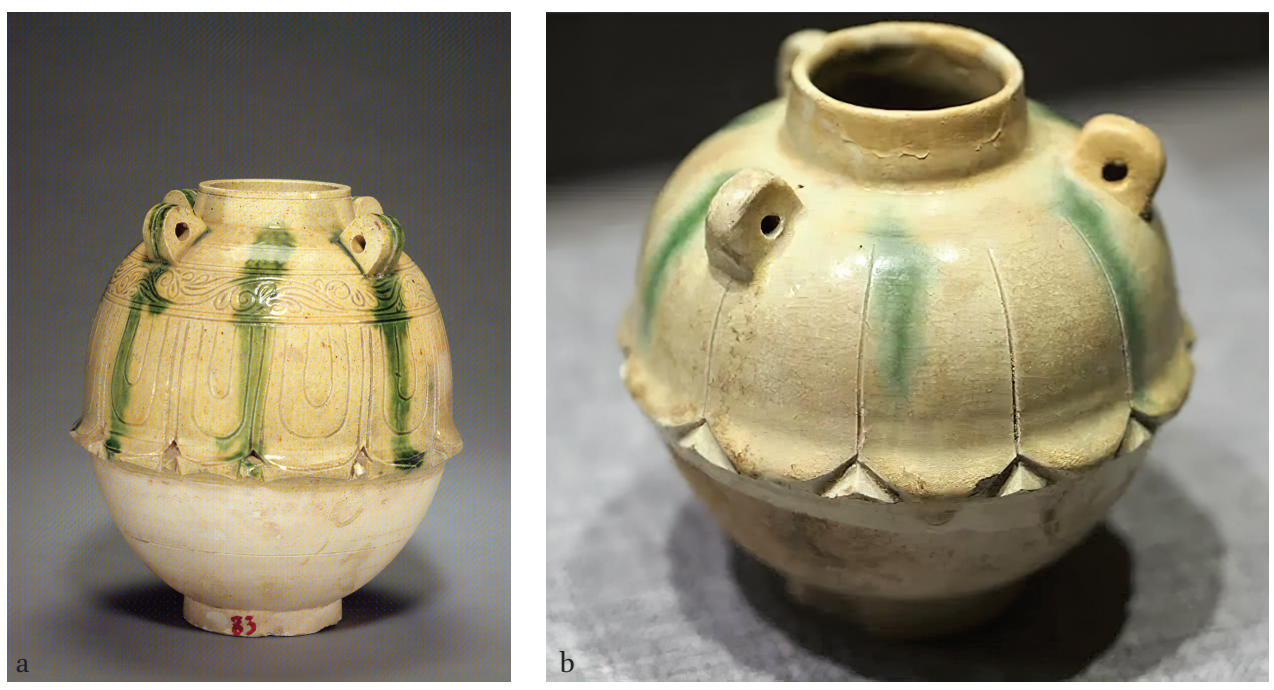

FIGURE 7

a. Light yellow glazed four-looped jar with green stripes, from the tomb of Li Yun, Northern Qi Dynasty, 576 CE; b. white glazed three-looped jar with green stripes, from the tomb of Fan Cui, Northern Qi Dynasty, 575 CE (C) A. PAlace museum; B. HENAN MUSEUM

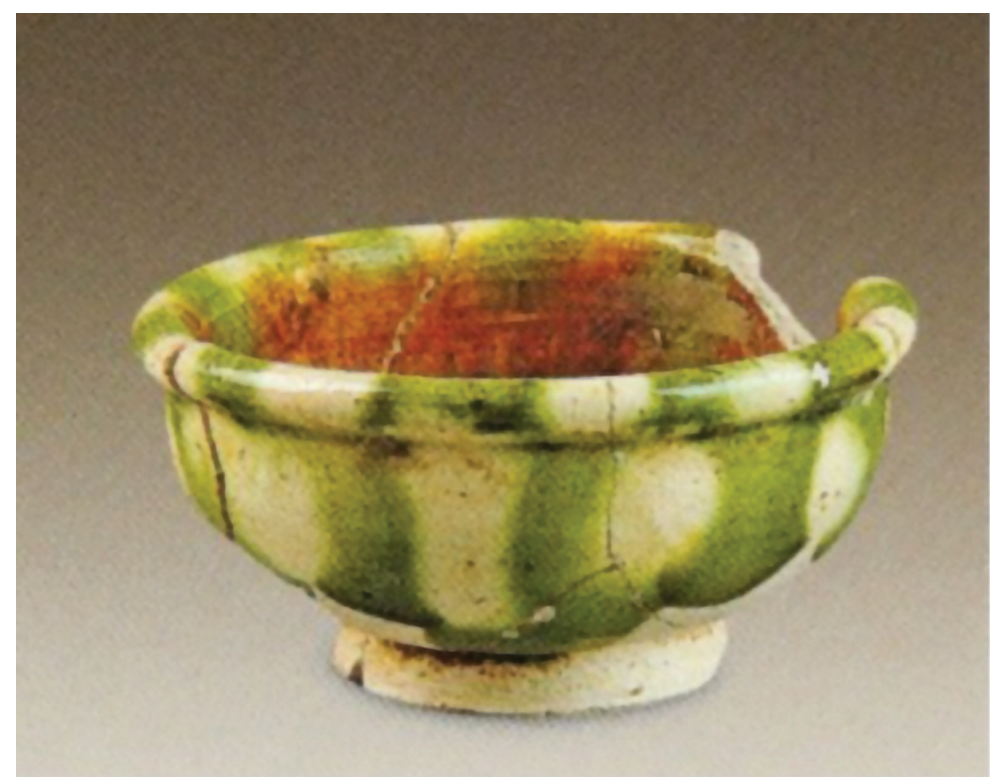

FIGURE 8

A white glazed bowl with green splashes from Huangye kilns, $684-756$ CE

(C) HENAN CULTURAL RELICS AND ARCHAEOLOGY INSTITUTE (2016: PLATE 59)

A number of kilns in China produced green splashed ware in the Tang period. At Huangye kilns (黄冶窑) (belonging to the Gongxian kilns in Henan Province), green splashed ware (Fig. 8) started to appear in the first half of the third period $(684-756 \mathrm{CE}$ ) of the production of kilns in a minor number. The production increased in the second half of the third period ( $756-84 \mathrm{O}$ CE) (Henan Cultural Relics and Archaeology Institute, 2016: 144, 301-2, 304-5, 325). Therefore, the production of green splashed white ware in China predates the ceramic exchange with the Abbasids which began in the late eighth and early ninth centuries CE and the Samarra Horizon Islamic green splashed ware in the ninth century. The production of Chinese green splashed ware was not inspired by its Islamic counterpart, neither was it imitation of Islamic green splashed ware. However, this does not necessarily mean the Islamic green splashed ware was imitation of its Chinese counterpart.

Some opaque yellow glazed ceramic sherds with green in-glaze paintings (Fig. 9) have been found in several archaeological sites in Syria including Qasr al-Hayr East, Apamea, al-Mina, Antioch, Aleppo, Raqqa and others. "The green seems to be applied as coloured glaze painted into the opaque yellow glaze before firing as random splashes 
FIGURE 9

Yellow glazed ceramic sherds from Raqqa, late eighth century CE (C) WATSON (2014: 140)

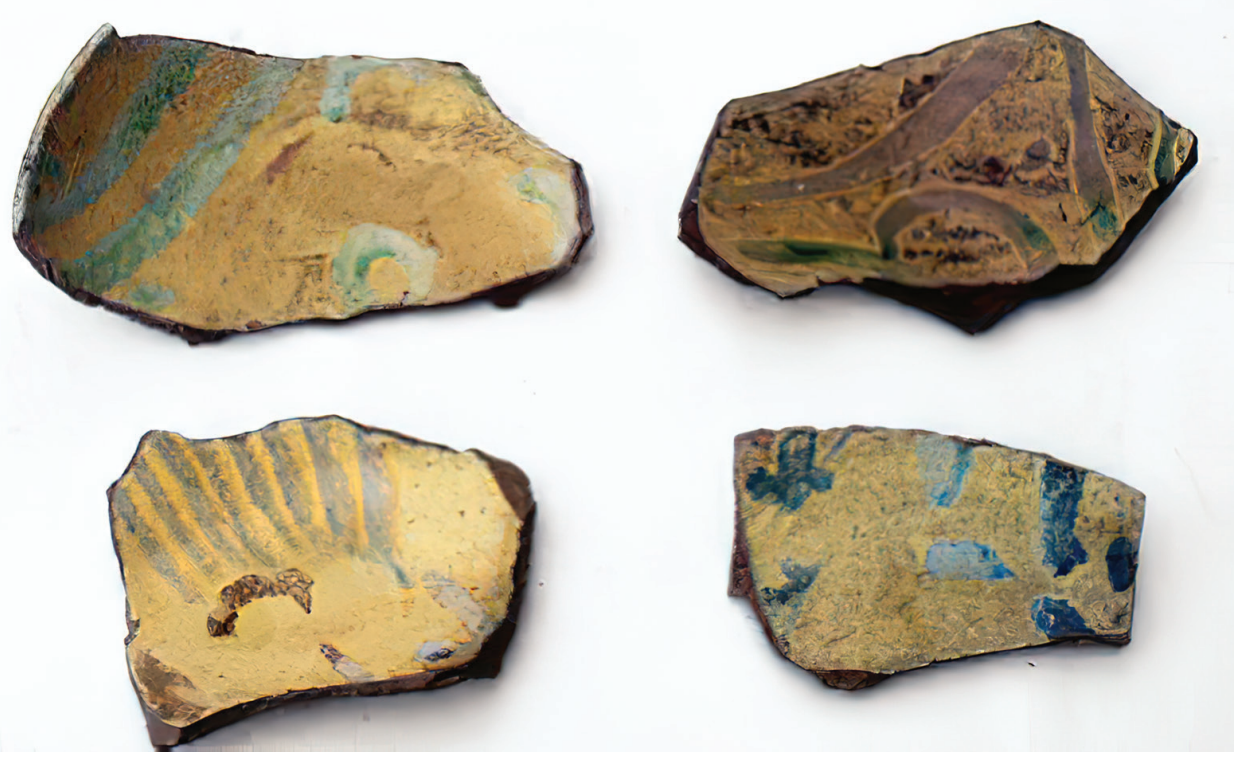

and runs or in more deliberate parallel streaks, or as yet more conscious patterns swags from the rim, curved lines dividing the surface and rows of dots" (Watson, 1999: 81-2). Evidence suggests that this yellow glazed green splashed ware was made at Tall Aswad (Watson, 1999: 84) no earlier than the mid-eighth century CE and was associated with the stay of the Abbasid caliph Harun al-Rashid (r. 786-809 CE) in Raqqa during 796-808 CE (Watson, 2014: 128, 130).

It seems that most Chinese green splashed white ware has either green splashes, patches or very neat dots. Whereas the Samarra Horizon green splashed white ware not only has green splashes, patches and dots, which resemble the Chinese ones, but also green streaks. Green streaks are rarely seen on Chinese green splashed white ware but are frequently featured on the early Islamic yellow glazed ware. The Samarra Horizon green splashed white ware might have taken influence from both Chinese green splashed white ware, which arrived in a number of places in the Islamic lands, and the early yellow glazed ware produced in Syria. However, this hypothesis needs to be examined by further research.

\subsection{Chinese Green Splashed Ware Found in Islamic Sites}

Fragments of Chinese green splashed white ware were found in Sohar (Rougeulle, 1991: 17, 19). In Zubalah, one shoulder fragment from a Chinese stoneware vessel with lead glaze similar to one from Siraf was found (Rashid, 1980: 280). No illustration or photo of this sherd has been published. Based on the study of Siraf ceramic finds, this Zubalah fragment may have been from green splashed ware. Only green splashed white ware fragments were found in Sirjan and Shahr-i-daqianus and the rest in village-level settlements and small ports in the Persian Gulf (Priestman, 2005: 307-8). ${ }^{1}$ In Fustat, both Scanlon and Tadanori have identified Chinese green splashed ware sherds from their excavations and surveys. ${ }^{2}$ A Chinese green splashed ware sherd (Fig. 10) was found in the 1980 excavation of Fustat (Scanlon and Kubiak, 1989: 48). It was found in the level dating to as late as the mid-eleventh century CE. This green splashed ware sherd was dated by Scanlon to the tenth century CE as a carry-over of the Cizhou (磁州) range of northern Chinese porcelain (Scanlon and Kubiak, 1989: 47). This opinion is not necessarily true. As discussed above, Huangye kilns had already produced green splashed 

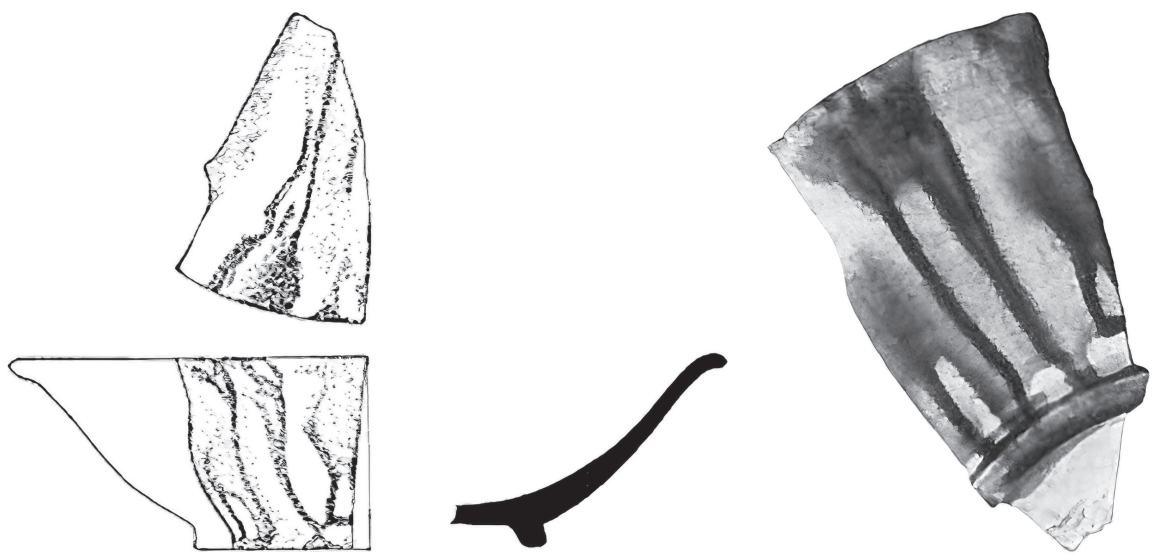

a

b

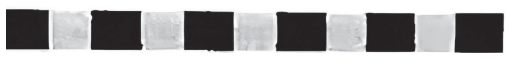

ware in the late seventh to early eighth centuries CE. And green splashed ware does not belong to the Cizhou ware range, which only came into being after the tenth century CE.

\subsection{Samarra}

Chinese green splashed white ware was also found in Samarra (Figs. 11-15). Some were given by people who picked them up in the ruins, which were recorded as hadiyya (هدية, gift) by Sarre. Others were found in the harem of Dar al-Khalifa (دار الخليفة, caliphal palace) (Sarre, 1925: 61, 63-4). Dar al-Khalifa was the principal residential palace for the
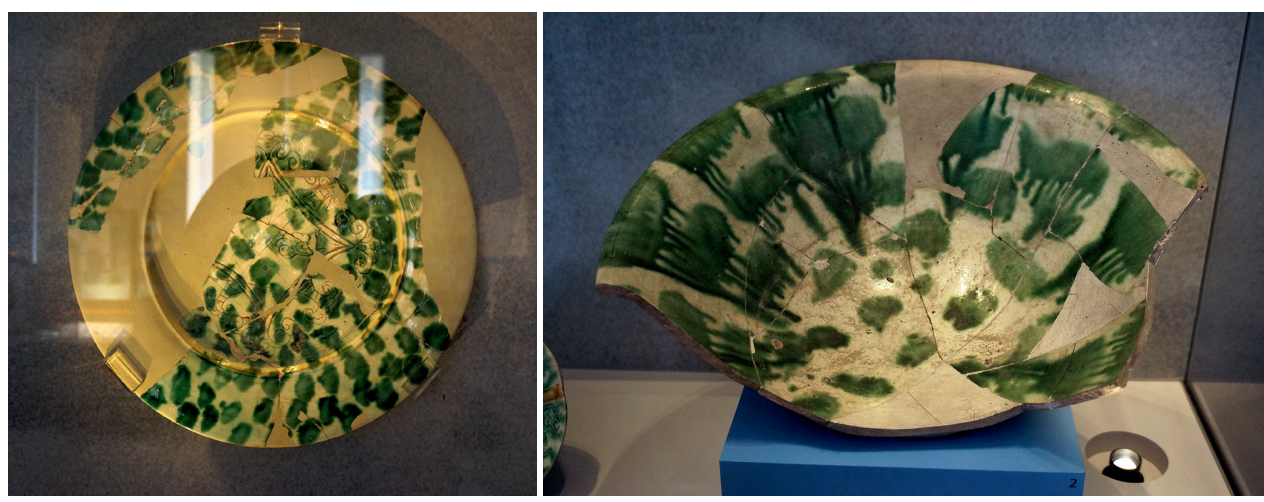

a

$\mathrm{b}$
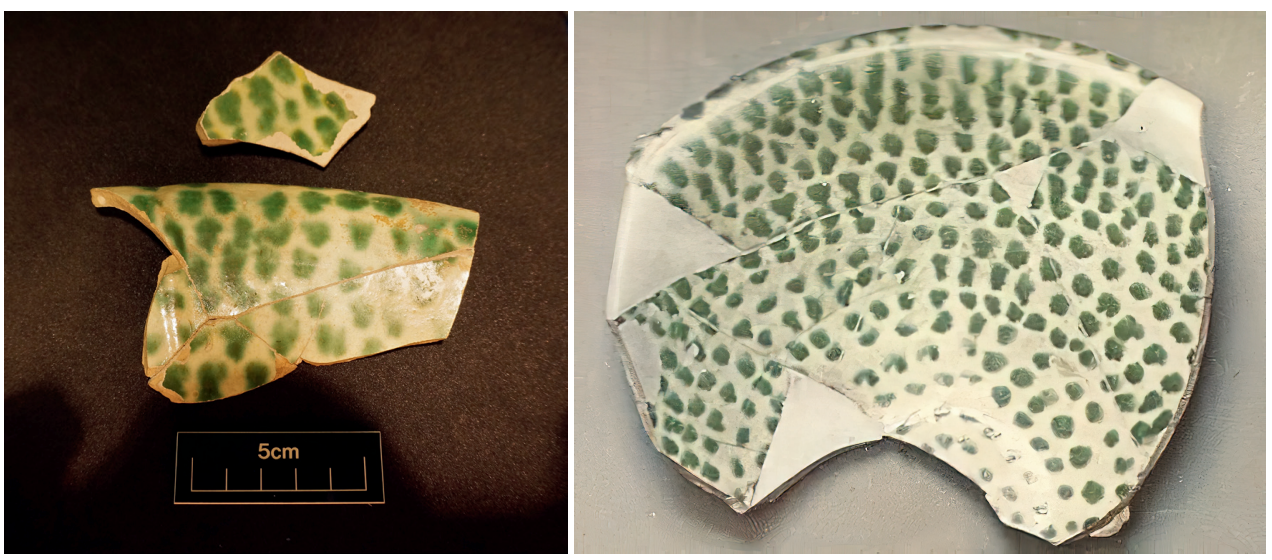

a

b
FIGURE 10

Chinese green splashed ware sherd found in Fustat

(C) SCANLON AND KUBIAK

(1989: 48)
FIGURE 11

a. Chinese flat dish with green spots and incised concave square with palmettes and spirals, found in the caliphal palace, ninth century $\mathrm{CE}$; b. fragments of a Chinese bowl with radial splashed decoration, found in the caliphal palace, ninth century CE (C) A. PHOTO TAKEN BY THE AUTHOR IN THE PERGAMON MUSEUM, ALSO IN SARRE (1925: NO. 220); B. PHOTO TAKEN BY THE AUTHOR IN THE PERGAMON MUSEUM, ALSO IN SARRE (1925: NO. 218)

FIGURE 12

a. Fragments of a Chinese white glazed bowl with green dots; $b$. fragments of a Chinese white glazed bowl with green dots (C) A. PHOTO TAKEN BY THE AUTHOR AT THE BRITISH MUSEUM; B. SARRE (1925: NO. 219, PLATE XXVI) 
FIGURE 13

Fragments of a Chinese white glazed dish with green and yellow dots

(C) SARRE (1925: NO. 221, PLATE XXVI)

FIGURE 14

a. and b. Fragments of Chinese green splashed ware; c. fragments of Chinese green and brown glazed ware with moulded dragon relief motif

(C) A. AND B. SARRE (1925:

NO. 226, PLATE XXIII); C. SARRE (1925: NO. 222, PLATE XXIII)
FIGURE 15

a. Fragments of Chinese green splashed ware with moulded relief decoration; b. fragments of Chinese green and brown splashed ware with moulded relief decoration

(C) A. SARRE (1925: NOS. 225 AND 223, PLATE XXIII); B. SARRE (1925: NO. 224, PLATE XXIII)
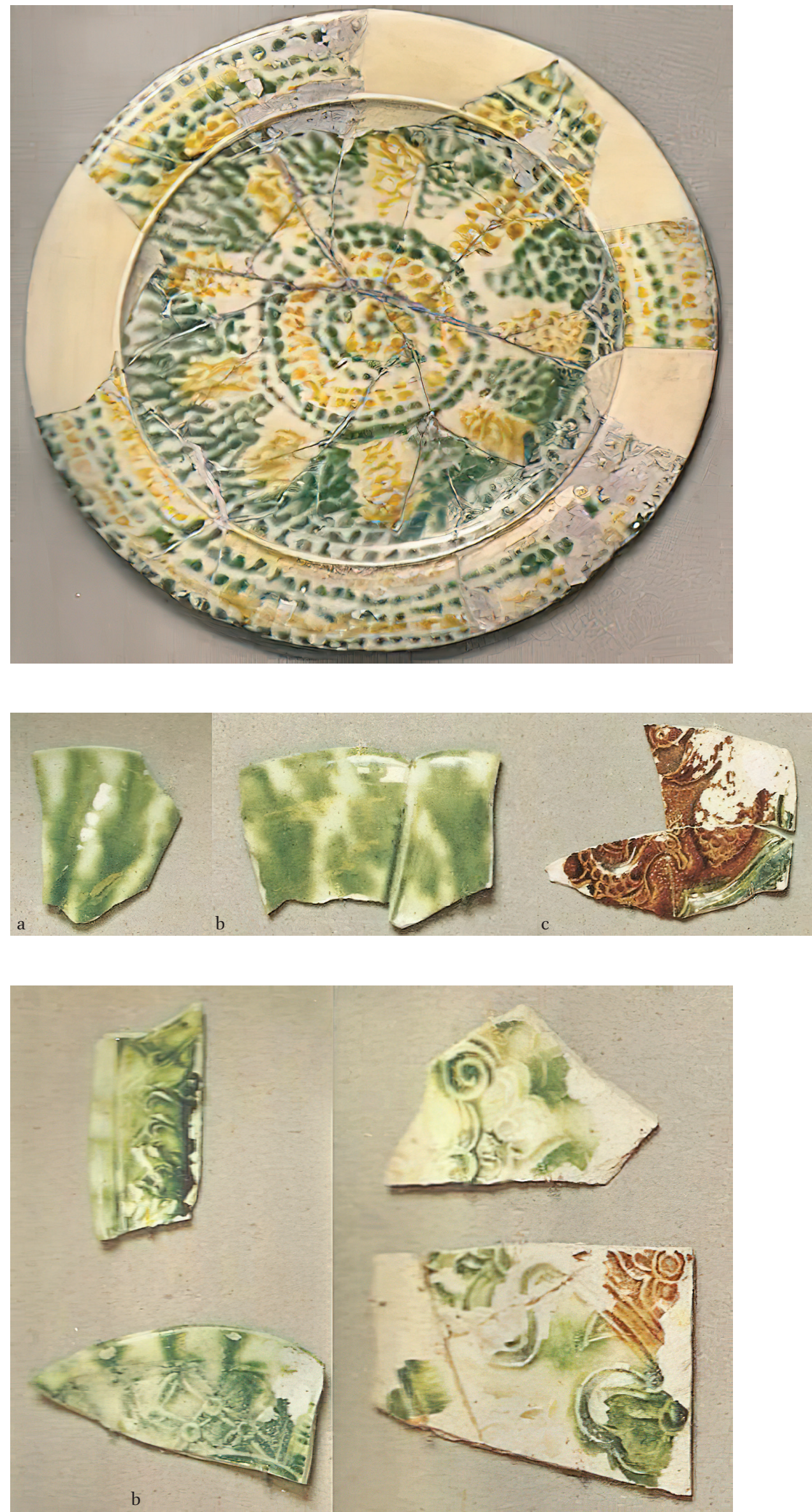

JOURNAL OF MATERIAL CULTURES IN THE MUSLIM WORLD 2 (2021) 150-183 

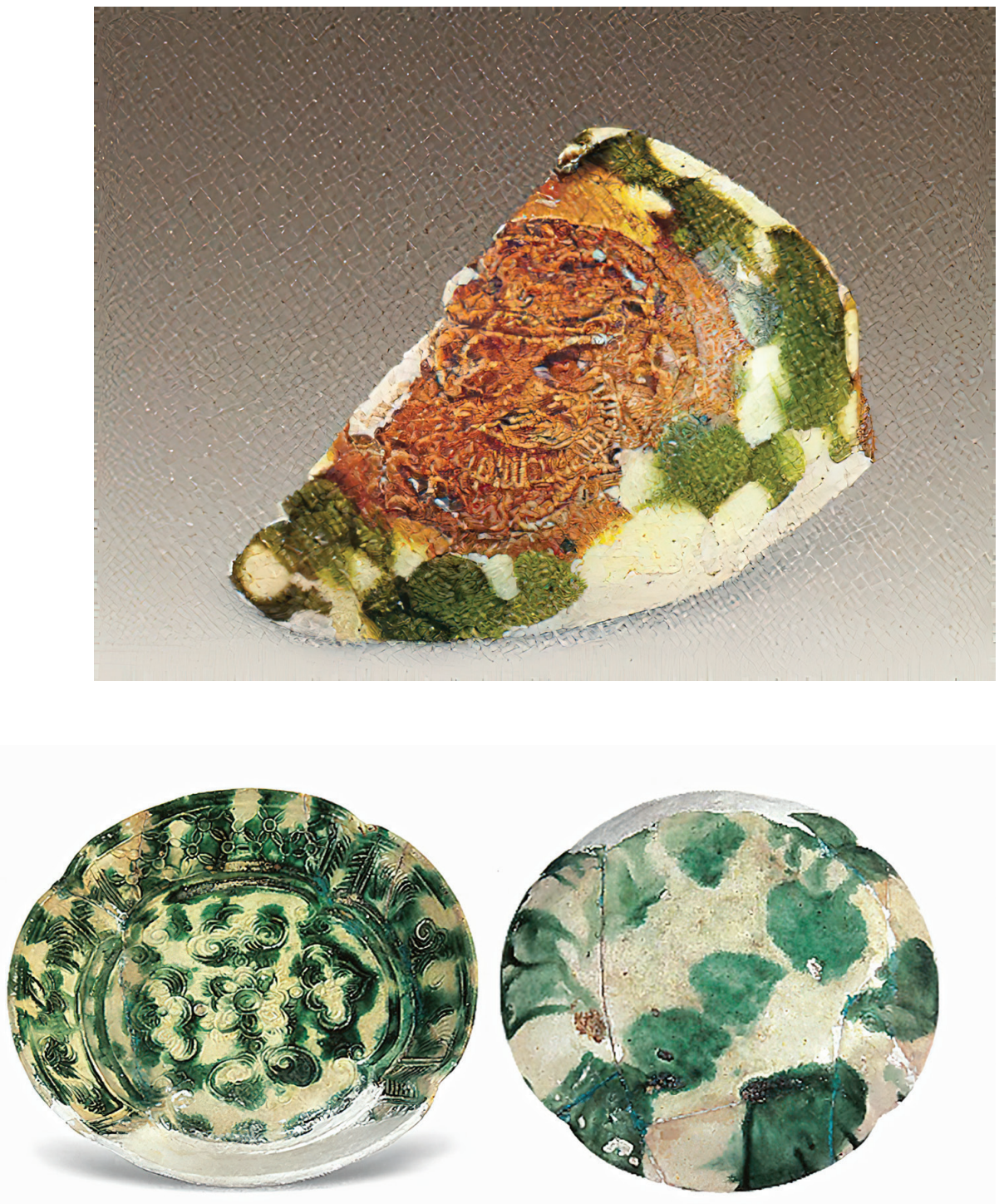

Abbasid caliphs in Samarra built in $836 \mathrm{CE}$ with its last known occupation in $884 \mathrm{CE}$ (Northedge, 2007: 135). One of the domed reception halls was excavated by Herzfeld and referred to as a harem (Northedge, 2007: 133). It is possible that some of these Chinese green splashed ceramics were supplied exclusively to the caliphal palace and once used in the harem. This also explains the limited amount of this type of ware found in Samarra and in the whole Abbasid caliphate.

The above green splashed white ware sherds presumably came from two kiln sites in China: Gongxian kilns and Xing kilns (邢窑). The fragments with brown and green patches and a moulded dragon relief decoration (Fig. 14c) were highly likely to be Gongxian products. Similar ones have been found in Gongxian kilns, such as this fragment of green splashed incense burner (Fig. 16) with a rounded patch of brown, beneath which is a moulded relief decoration of a musician playing a lute. The above fragments with relief decorations (Fig. 15) were likely from Xing kilns. Xing kilns have yielded a green splashed white glazed dish with moulded floral and geometric patterns (Fig. 17) which resemble many of the patterns on these Samarra fragments.

Some Chinese green splashed white ware fragments found in Samarra are embellished with neatly applied dots (Figs. 12 and 13). Identical sherds (Fig. 18) were found in
FIGURE 16

A fragment of incense burner from Gongxian kilns (C) HENAN CULTURAL RELICS AND ARCHAEOLOGY INSTITUTE (2016: PLATE 126)

\section{FIGURE 17}

A white glazed dish with green splashes and moulded relief decorations from Xing kilns, Tang dynasty (C) ZHAO QINGGANG AND ZHANG ZHIZHONG (2007: 211) 
FIGURE 18

Gongxian green splashed white glazed dish found in Yangzhou (C) INSTITUTE OF ARCHAEOLOGY, CHINESE ACADEMY OF SOCIAL SCIENCES ET AL. (2010: PLATE 118)
FIGURE 19

A Chinese green splashed cup fragment with "drinking tube" found in Samarra (the smaller piece on the right)

(C) PHOTO TAKEN BY THE AUTHOR AT THE BRITISH MUSEUM
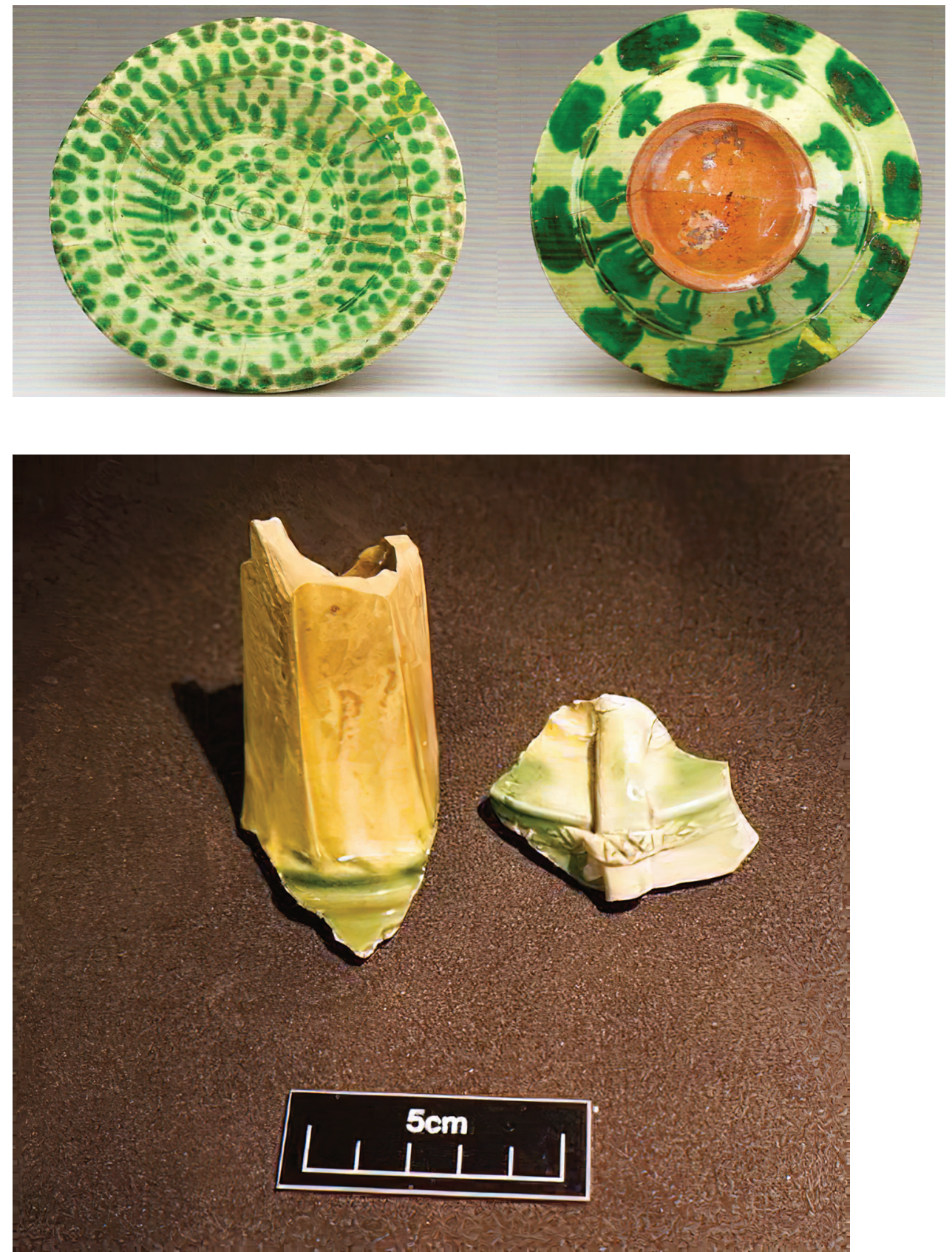

the excavations of the ancient Yangzhou port which were produced in Gongxian kilns. This further substantiates the link between the ancient Yangzhou port and the Abbasid lands in the Indian Ocean maritime network and exchange.

A fragment of green splashed white glazed cup with a "drinking tube" (Fig. 19) was found in Samarra. This type of cup has also been found in the Belitung shipwreck rescued off the Belitung Island in the Java Sea (Fig. 20) and from the excavations of Huangye kilns (Fig. 21) dating to the period between 841 and $907 \mathrm{CE}$ (Henan Cultural Relics and Archaeology Institute, 2016: 218). Almost without doubt this Samarra cup was produced in Huangye kilns at some point between 841 and $907 \mathrm{CE}$. This also provides evidence to argue that the Belitung ship was wrecked after $840 \mathrm{CE}$ and with a final destination possibly to the Abbasid lands via the Persian Gulf. ${ }^{3}$ 

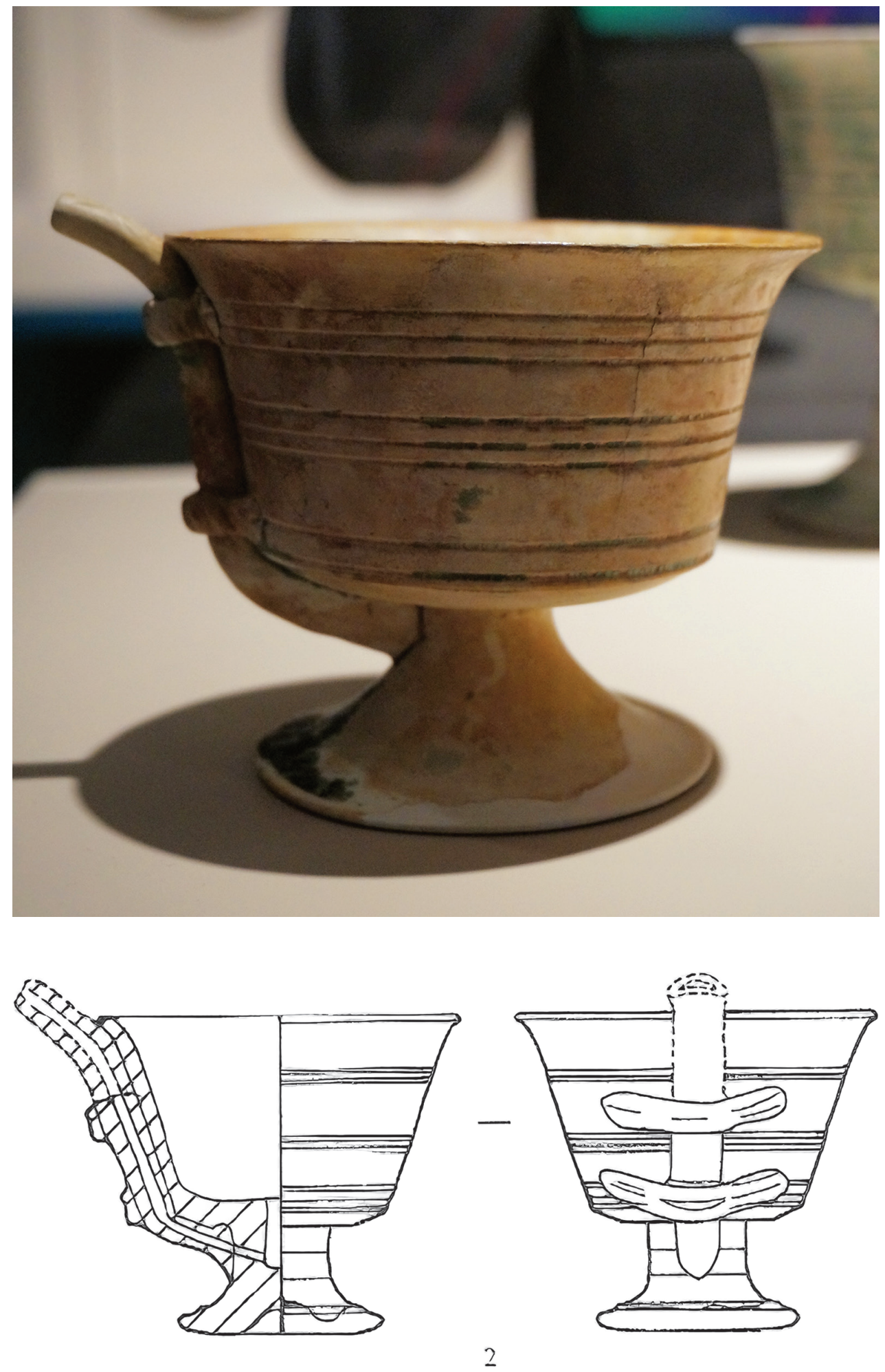

\subsection{Nishapur}

A fragment of green lead glazed vessel with a moulded medallion of a dragon in the middle (Fig. 22a) was found from the excavations of Nishapur (Wilkinson, 1973: 257). It is now in the Metropolitan Museum of Art dating to the late seventh to the first half of the eighth centuries $\mathrm{CE}$ by the museum. A bowl with almost identical green splashed white glaze and moulded dragon medallion relief was found in the ancient Yangzhou port (Fig. 23a) and another two from the Belitung shipwreck (Figs. 22b and 23b). Based
FIGURE 20

A green splashed cup with "drinking tube" from the Belitung shipwreck

(C) PHOTO TAKEN BY THE AUTHOR IN NEW YORK

FIGURE 21

A green splashed cup with "drinking tube" from the Huangye kilns

(C) HENAN CULTURAL RELiCS AND ARCHAEOLOGY INSTITUTE (2016: 218) 
FIGURE 22

a. A Chinese green lead glazed sherd with a dragon motif from Nishapur; b. four-lobed bowl with dragon medallion, probably from Gongxian kilns, found in the Belitung shipwreck

(C) A. METROPOLITAN MUSEUM OF ART; B. PHOTO TAKEN BY THE AUTHOR IN NEW YORK

\section{FIGURE 23}

a. A green splashed white glazed four-lobed bowl with dragon relief, possibly from Gongxian kilns, found in the ancient Yangzhou port in 1983 ; b. a similar bowl from the Belitung shipwreck

(C) A. YANGZHOU MUSEUM; B. ASIAN CIVILISATIONS MUSEUM

\section{FIGURE 24}

a. A Tang silver bowl with gilded moulded relief decoration from the hoard of Hejiacun, Xi'an; b. a Sasanian silver bowl with medallion relief, fourth century CE (C) A. SHA'ANXI HISTORY MUSEUM; B. METROPOLITAN MUSEUM OF ART
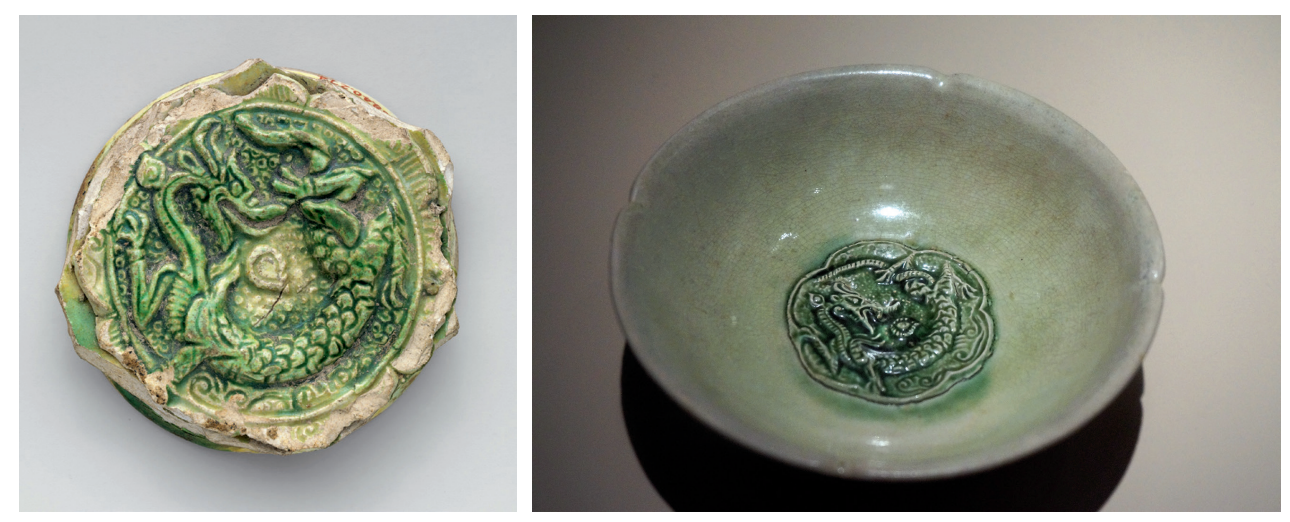

a

b

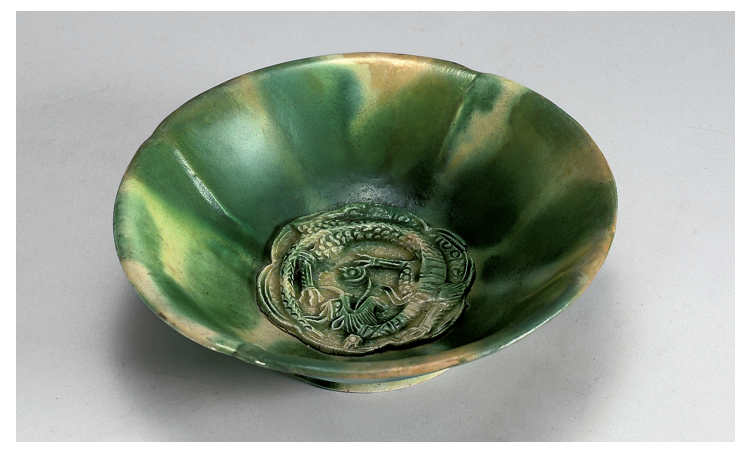

a

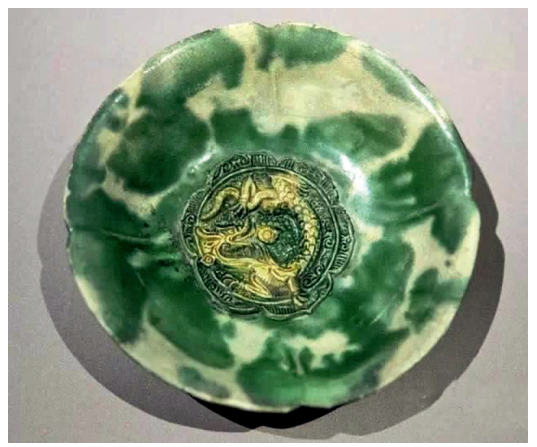

b
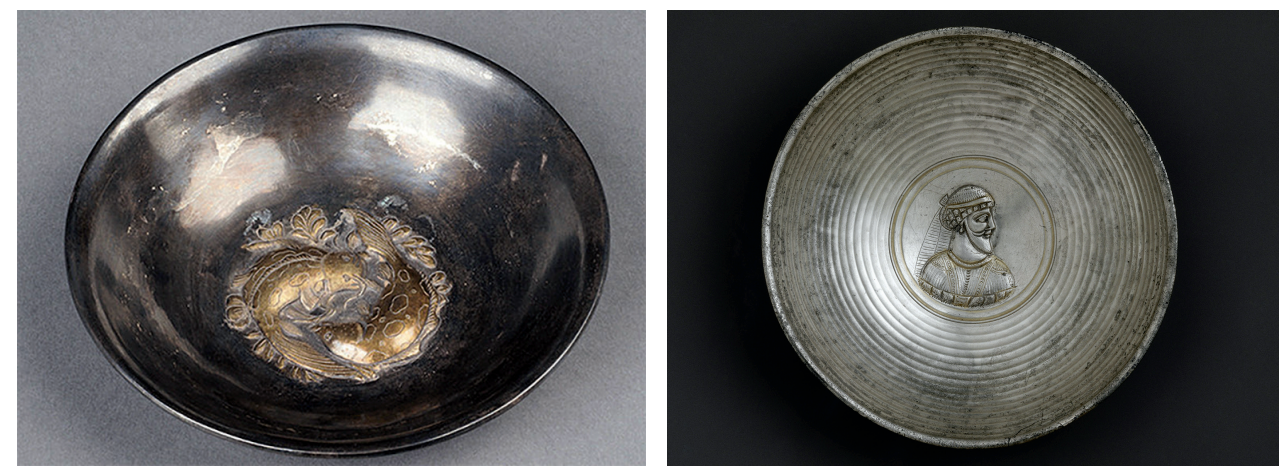

a

b

on the evidence presented by the green splashed cup with "drinking tube," the Belitung ship was most likely wrecked after 840 CE. Therefore, these two dragon medallion bowls found in the Belitung shipwreck can also be dated after $840 \mathrm{CE}$. The Metropolitan Museum's dating of this Nishapur fragment is probably too early. This type of dragon medallion green splashed bowls could not possibly have been produced earlier than the ninth century CE, and most likely in the 84OS CE.

Although the dragon motif is of Chinese style and the ring foot is typical to ceramic bowls during the Tang period, the shape and moulded relief of the above vessels were borrowed from contemporary metalworks, such as this silver bowl with gilded moulded relief decoration found in the hoard of Hejiacun (何家村) in Xi'an, China (Fig. 24a). This silver bowl was influenced by earlier Persian silverworks with relief medallion motif (Fig. 24b), though the twin fish motif is of indigenous Chinese style. 


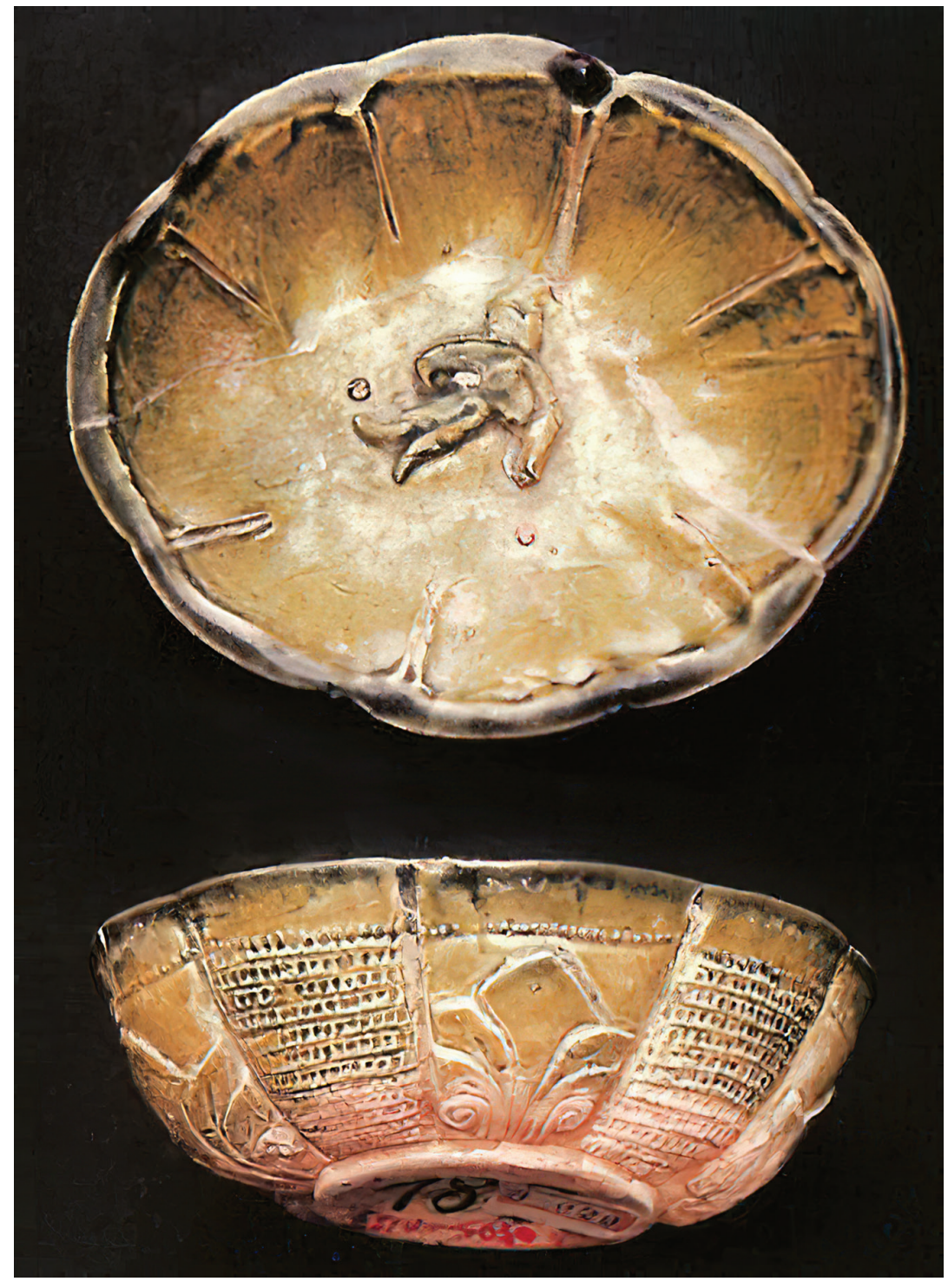

This type of bowl was most likely produced in Gongxian kilns. Similar ones have been found in Gongxian kilns, such as this yellow-green glazed multi-lobed bowl (Fig. 25) with a moulded decoration on the interior, engraved decorations and lines of poked dots on the exterior. This Gongxian bowl is also an imitation of a metalwork prototype. A green glazed cup with moulded fish medallion decoration covered by yellow glaze (Fig. 26a) was found at the archaeological site of the Tang West Market in Xi'an. Its moulded medallion decoration resembles those found in Nishapur, the Belitung shipwreck and Yangzhou port. This West Market cup was most probably produced by Gongxian kilns. Almost identical monochrome green glazed cups with moulded fish medallion decoration on the interior (Fig. 26b) were found in Huangye kilns dating to around $841-907 \mathrm{CE}$. This also provides evidence to the dating of these dragon medallion bowls to the ninth century CE possibly after $84 \mathrm{O} \mathrm{CE}$.

Chinese potters learnt this idea from contemporary metalworks, which were imitating earlier Sasanian metalworks. These Chinese ceramics with a Sasanian metalwork prototype found their way to the Yangzhou port, shipped to the Middle East and to Nishapur in Iran. So far, only four of this type of ware are known. They were probably never mass produced and were supplied exclusively to Abbasid patrons as gift or tribute rather than commercial traded goods. Both the green splashes and the medallion relief decorations may have appealed to these Abbasid patrons.

\section{FIGURE 25}

A yellow-green glazed bowl with relief decoration from Huangye kilns

(C) GONGYI MUNICIPAL OFFICE FOR THE PRESERVATION OF ANCIENT MONUMENTS, HENAN PROVINCE (2000: PLATE 18) 
FIGURE 26

a. A green glazed cup with yellow glazed moulded fish decoration found at the Tang West Market site in Xi'an; b. a monochrome green glazed cup with moulded fish decoration found in the Huangye kilns (C) A. PHOTO TAKEN BY THE AUTHOR AT THE TANG WEST MARKET MUSEUM; B. HENAN CULTURAL RELICS AND ARCHAEOLOGY INSTITUTE (2016:218)
TABLE

Sites in Siraf with Chinese green splashed ware sherds (c) WEN WEN
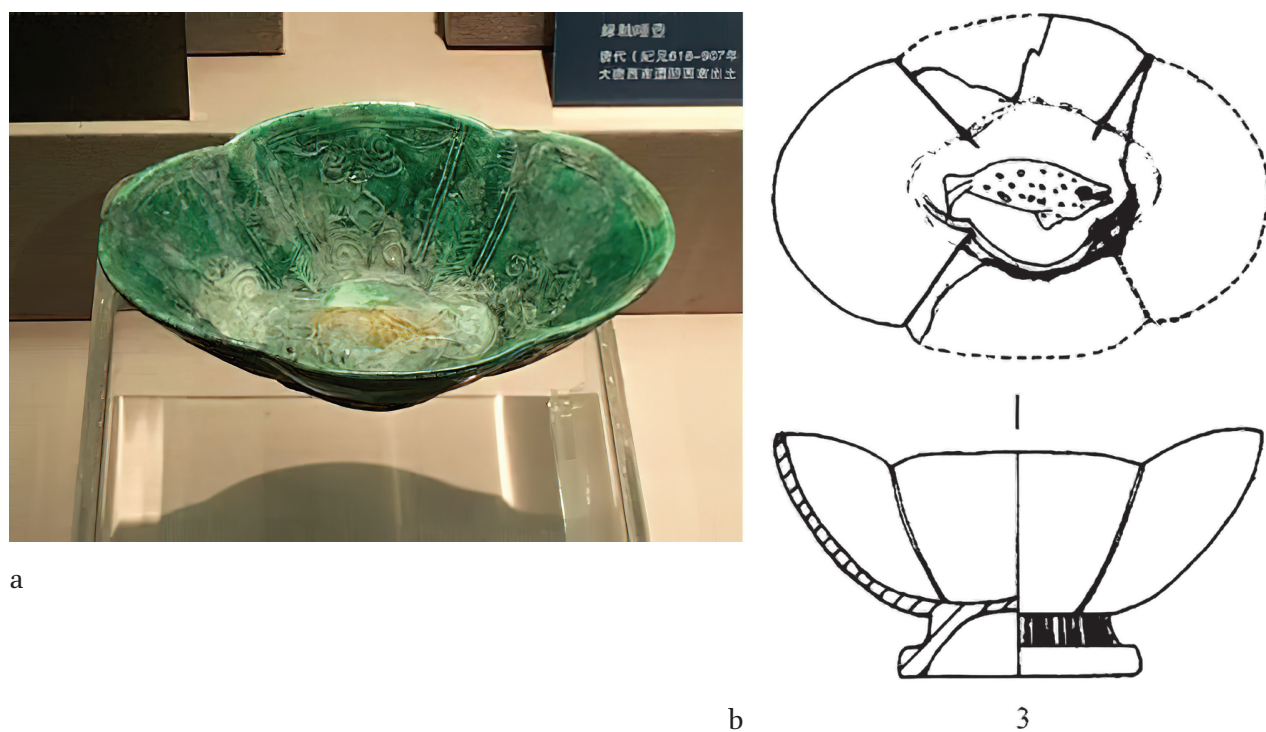

4.4 Siraf

There are around sixty-three fragments of Chinese green splashed ware found in Siraf at the British Museum. Forty-four fragments were from green splashed white ware, twelve fragments in monochrome green glaze with moulded relief decoration, four green splashed sherds with some yellow stains, two fragments of white glaze with green and yellow splashes and one fragment with yellow glaze and green splashes.

Among these green splashed sherds, two were from jars, twenty-six from dishes, with the rest from bowls. The finding locations of these sherds are shown in Table 1. Fifteen individual sites have been excavated in Siraf; nine sites have Chinese splashed ware finds. Unlike in Samarra, there seems to be no positive correlation between this type of ware and the finding locations. It should also be pointed out that almost all the Siraf Chinese green splashed sherds are rather fragmentary and tiny, which indicates that many of them may have just come from the same vessel. Therefore, the amount of Chinese green splashed ware initially shipped to Siraf may have been very limited like the case in Samarra.

Most of these Siraf sherds have been identified as products from kilns in Henan Province and north China with very few from Changsha kilns. ${ }^{4}$ Closer examination indicates that these Siraf sherds presumably belong to Gongxian kilns and Xing kilns in north China and Changsha kilns (Fig. 27) in south China.

Site code ${ }^{\mathrm{a}}$

Number of sherds

Site A: Sounding 4

Site B: Sasanian citadel and congregational mosque $\quad 5$

Site C: Bazaar

Site D: Pottery quarter

Site E: Residential compound, fifteenth century CE

Site F: Residential quarter, tenth to eleventh centuries CE

Site K: Palatial residence

Site M: Mosques, defensive wall and buildings near the shore

Site P: Mosques, defensive wall and buildings near the shore

Unknown site

5

3

1

13

5

13

9

9

a See Whitehouse (2009) for the site codes and excavations of Siraf. 


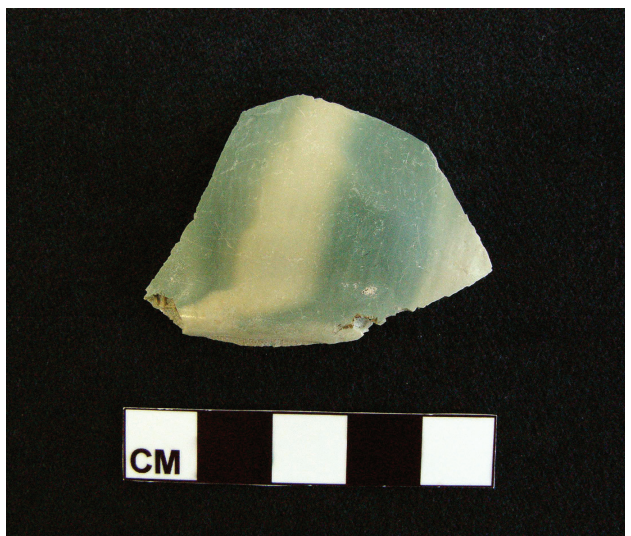

a

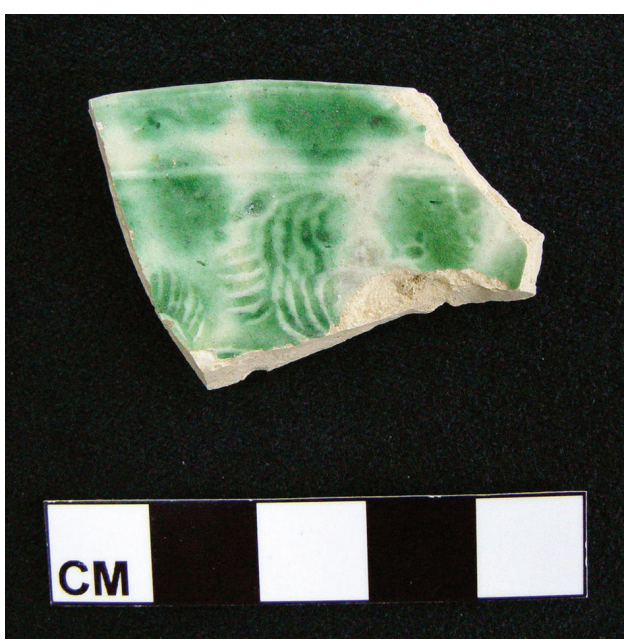

a

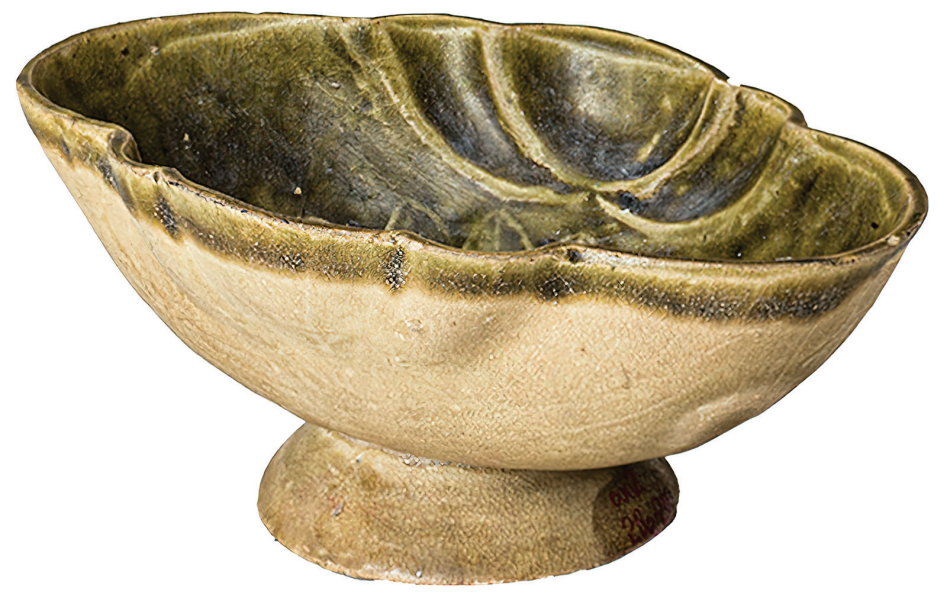

There are around sixteen fragments with moulded relief decoration, twelve of which are in monochrome green and four fragments in white glaze with green splashes (Fig. 28). Xing kilns and Changsha kilns both have produced monochrome green and green splashed ware with moulded relief decoration on the interior walls. ${ }^{5}$ The moulded relief decoration and the thinly potted walls resemble features of contemporary metalworks. Similar ones were found from the excavations of Changsha kilns, though in olive green and bluish green glaze rather than the green glaze found on these Siraf sherds (Figs. 29-31).

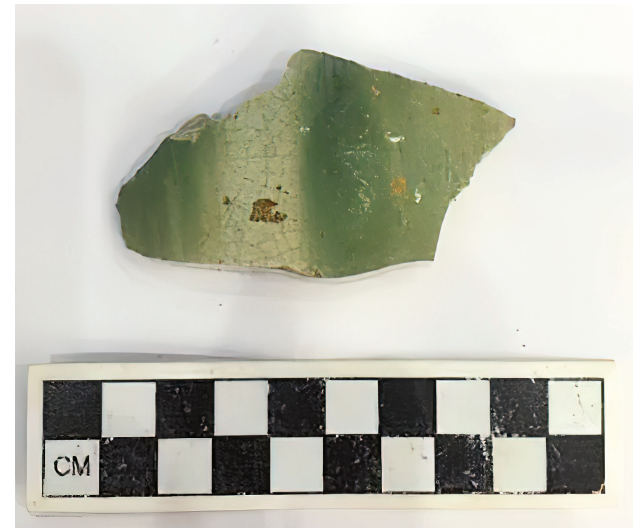

b

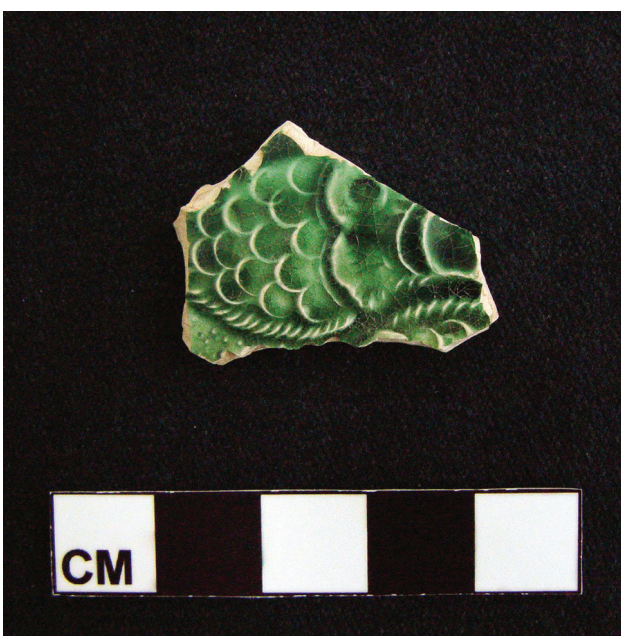

b

\section{FIGURE 29}

A Changsha monochrome green glazed cup with moulded decoration

(C) CHANGSHA MUSEUM 
FIGURE 30

A Changsha monochrome bluish green glazed cup with moulded decoration, at the Bureau of the Management of the Changsha Kilns

(C) PHOTO TAKEN BY THE AUTHOR

FIGURE 31

A Changsha monochrome olive green glazed dish with moulded decoration, at the Bureau of the Management of the Changsha Kilns

(C) PHOTO TAKEN BY THE AUTHOR
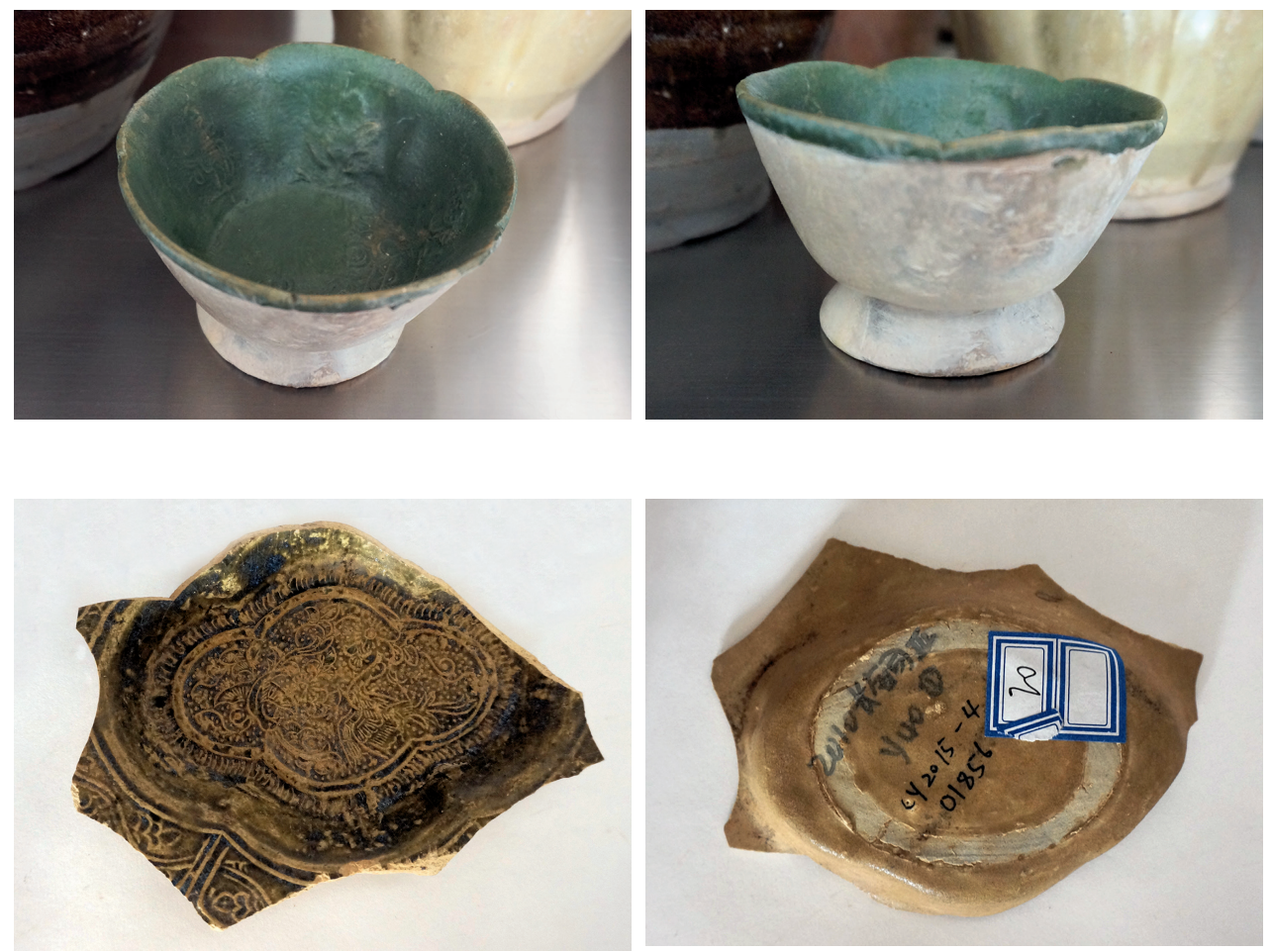

5 White Ware with Blue Paintings

Huangye kilns are known to have produced white ware with blue paintings (Fig. 32) at least from the period of $684-756 \mathrm{CE}$ (Jia Chenghui et al., 2007: 491-5). This predates the production of Islamic blue painted white ware in the early ninth century CE. ${ }^{6}$ In the beginning, these blue painted white ceramics were low-fired earthenware. High-fired blue painted white ware in Huangye kilns was only produced in around 841-907 CE (Henan Cultural Relics and Archaeology Institute, 2016: 17). High-fired blue painted

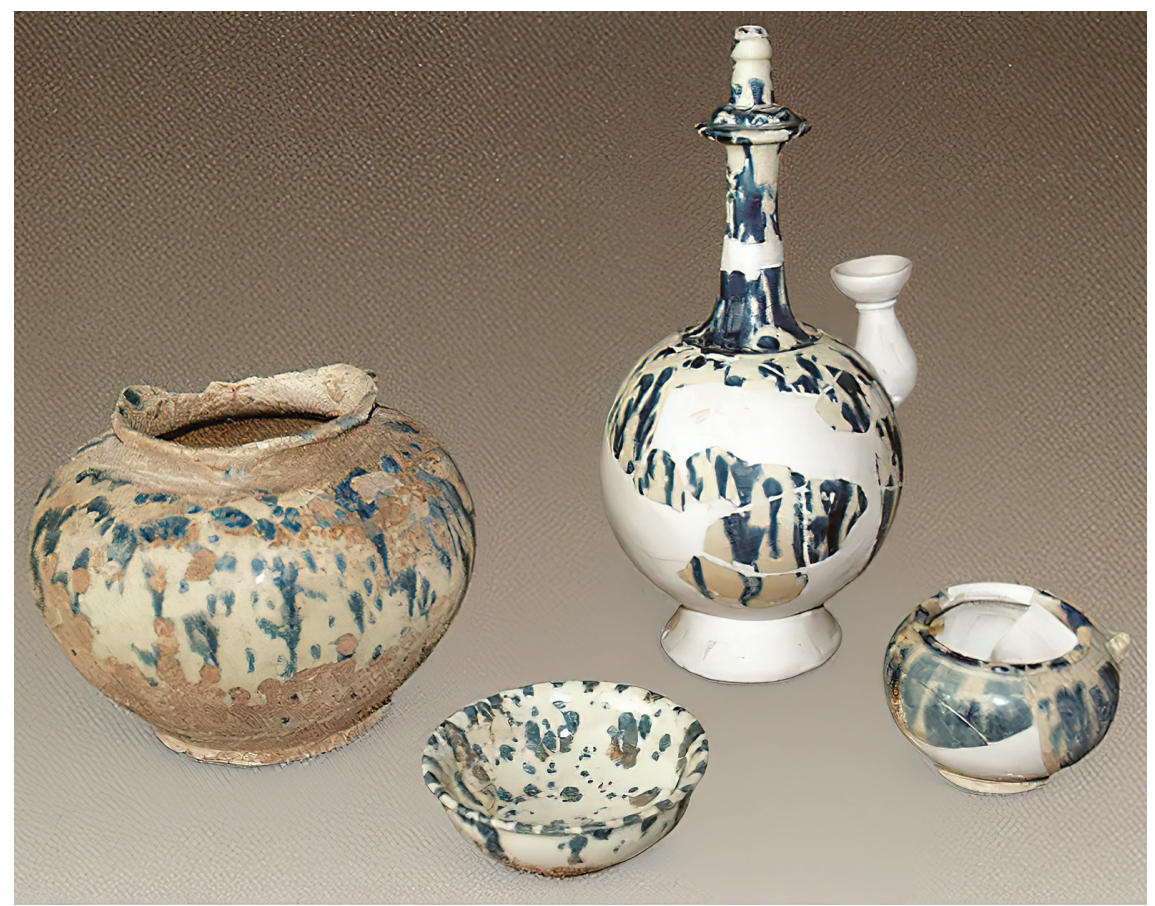

FIGURE 32

Chinese white ware with blue paintings from Huangye kilns, $684-756 \mathrm{CE}$

(C) HENAN CULTURAL RELICS AND ARCHAEOLOGY INSTITUTE (2016: PLATE 259) 

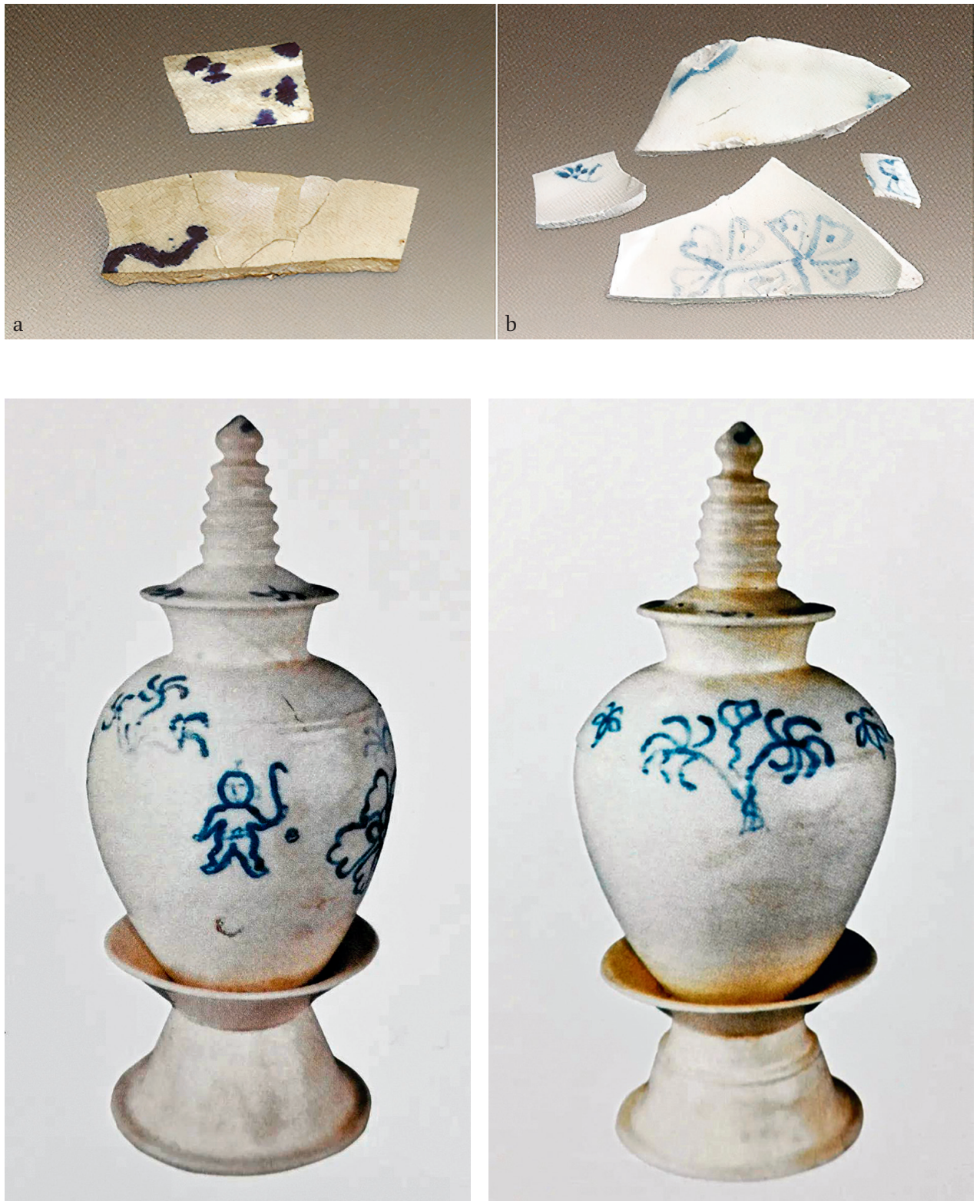

white ware was also found from the excavations of Baihe kilns (白河窑) (belonging to Gongxian kilns), though the Baihe kiln's ware cannot be dated precisely. Nigel Wood has explained that the blue pigment or glaze on Chinese ware was applied both beneath and on top of the base glaze. Islamic early blue and white ware also adopted different approaches to achieve this visual effect by using blue pigment or glaze on or in the base glaze (Wood and Tite, 20o9: 26). Decorations on Chinese blue painted white ware comprise curved lines with floral and lozenge patterns (Henan Cultural Relics and Archaeology Institute, 2016: 307).

High-fired blue painted white stoneware has been found in several locations. A blue and white jar and a fragment of a blue and white ewer (Fig. 33a) were found in the excavations of Huangye kilns, dating to the period of around 841-907 CE (Henan Cultural Relics and Archaeology Institute, 2016: 17). Two blue and white pagoda-shaped jars (Fig. 34) were found in a Tang tomb in Zhengzhou, Henan Province, not far from the Gongxian kilns in 2006. Excavations of the ancient Yangzhou port yielded a noticeable amount of blue and white stoneware vessels and fragments (Figs. 35 and 36). A blue and white stoneware pillow with geometric patterns was found in the 1975 excavations of
FIGURE 33

a. Tang blue and white stoneware sherds from Huangye kilns, around 841-907 CE; b. Tang blue and white stoneware sherds from Baihe kilns

(C) A. HENAN CULTURAL RELICS AND ARCHAEOLOGY INSTITUTE (2016: PLATE 232); B. HENAN CULTURAL RELICS AND ARCHAEOLOGY INSTITUTE (2016: PLATE 262)
FIGURE 34

Two Tang pagoda-shaped blue and white stoneware jars from a tomb in Zhengzhou (C) ZHENGZHOU MUNICIPAL INSTITUTE OF CULTURAL RELICS AND ARCHAEOLOGY 
FIGURE 35

Tang blue and white stoneware sherds from the ancient Yangzhou port

(C) HENAN CULTURAL RELICS AND ARCHAEOLOGY INSTITUTE (2016: PLATE 270)
FIGURE 36

Tang blue and white stoneware sherds from the ancient Yangzhou port, late Tang period (C) Institute OF ARCHAEOlOGY, CHINESE ACADEMY OF SOCIAL SCIENCES ET AL. (2010: PLATE 115)
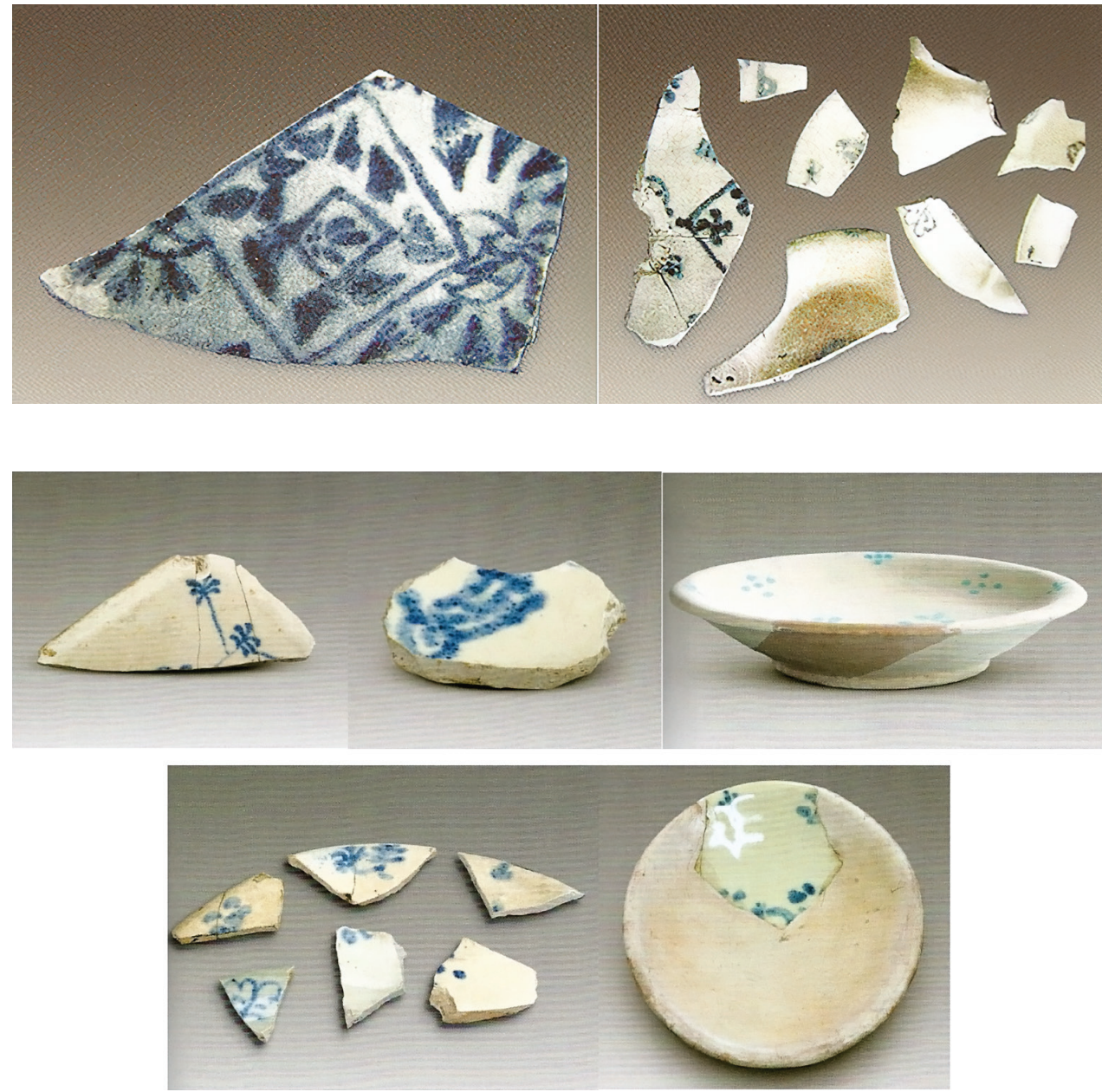

the ancient Yangzhou port. More than twenty pieces of Tang blue and white stoneware were collected in 1983. In 1990, excavations in Yangzhou yielded another fourteen pieces of Tang blue and white stoneware (Institute of Archaeology, Chinese Academy of Social Sciences et al., 2010: 148-78). Analysis of these Tang blue and white stoneware sherds shows that they were fired at around $1250^{\circ} \mathrm{C}$ with a slip between the body and glaze painted with cobalt blue under the glaze. It also reveals that the cobalt pigment used by the Tang blue and white stoneware was from a sulphur cobalt mine with iron and copper elements and less silicon oxide and aluminium oxide, which is chemically different from that used by Yuan and Ming blue and white porcelain (Henan Cultural Relics and Archaeology Institute, 2016:318). Whereas contemporary Islamic blue painted ware used a cobalt ore of an iron-cobalt mixture often containing some copper and always some zinc, which is lacking in the cobalt pigment used on Chinese Tang blue and ware (Wood and Tite, 2009: 28). Chinese blue painted ware and its Islamic counterpart used different cobalt ores for their blue pigments. And it remains unknown whether cobalt ores in the Middle East and Central Asia were ever exported to China and used on Gongxian wares. On the Belitung shipwreck were three intact blue and white stoneware dishes (Fig. 38) which are now in the Asian Civilisations Museum in Singapore. The University of Hong Kong Museum and Art Gallery (Fig. 37) and the Museum of Fine Arts of Boston also collect a few Tang blue and white stoneware vessels (Henan Cultural Relics and Archaeology Institute, 2016: 315). Siraf is currently the only site in the Islamic lands with one sherd of Tang blue and white stoneware. The blue dots decoration on this Siraf high-fired blue painted white stoneware can be traced back to the 

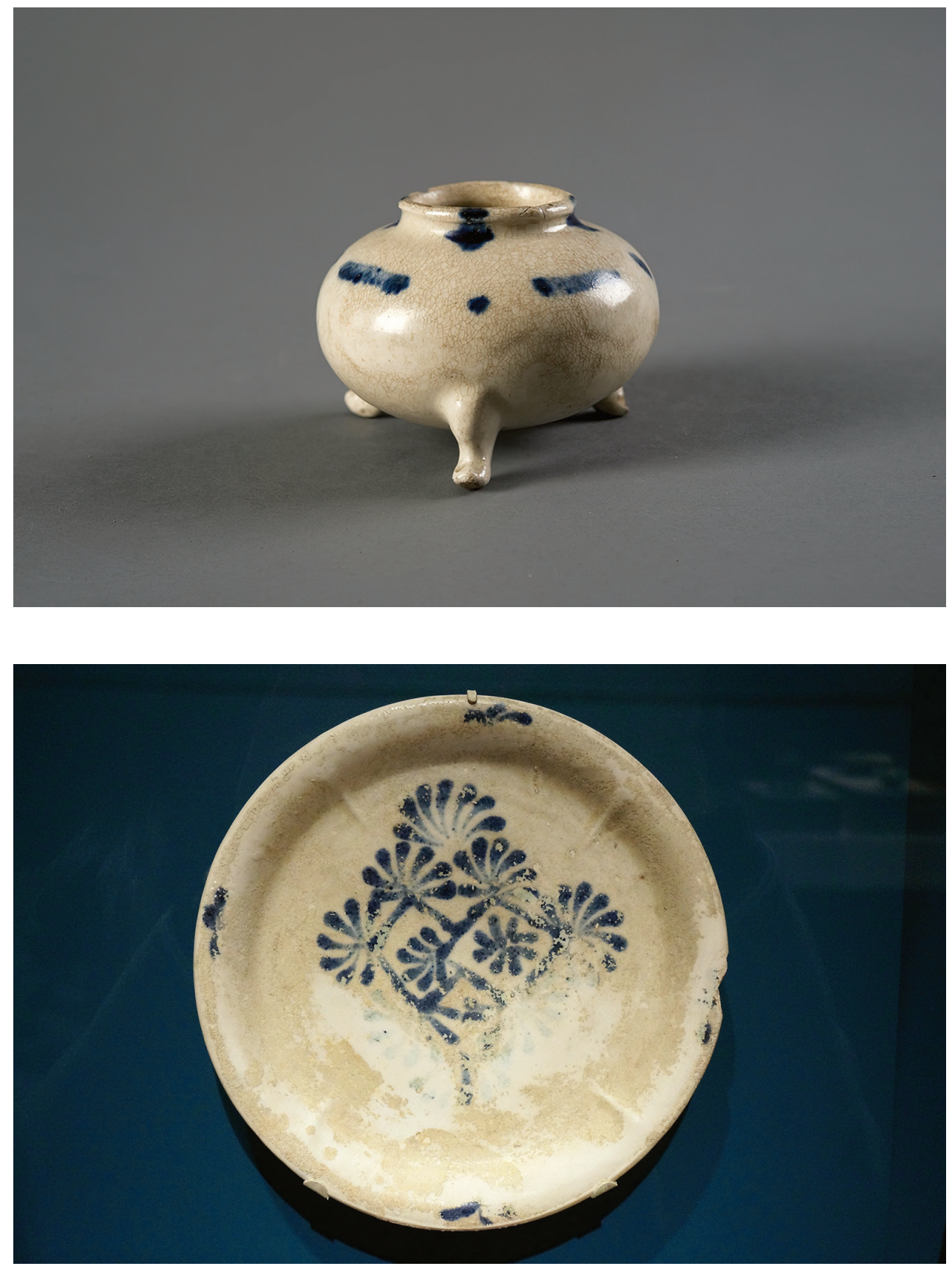

FIGURE 37

A Tang cobalt blue tripod stoneware pot (C) UNIVERSITY OF HONG KONG MUSEUM AND ART GALLERY, HKU.C.1953.0028
FIGURE 38

A Tang blue and white stoneware dish from the Belitung shipwreck (C) PHOTO TAKEN BY THE AUTHOR IN NEW YORK earlier low-fired blue painted white ware produced in Gongxian kilns (Fig. 39) during the period of $756-840 \mathrm{CE}$.

Chinese low-fired blue painted white ware was produced much earlier than the Samarra Horizon blue painted white ware. Therefore, it is impossible that the production in China was inspired by its Islamic counterpart. At some point in the early ninth century CE, high-fired blue painted white ware was produced in China. It is believed that the Abbasids started the production of white ware with cobalt blue paintings in the early ninth century soon after the arrival of Chinese ceramics (Northedge and Kennet, 1994: 25). However, there is so far only one fragment of Chinese blue painted white ware found in the Islamic world in Siraf. It is inconclusive that the Samarra Horizon Islamic blue painted white ware in the ninth century was imitation of the Chinese one.

The production of Chinese high-fired blue painted white ware in the early ninth century was likely linked to the material exchange and interactions between the Abbasids 
FIGURE 39

a. A fragment of Chinese blue painted white stoneware from Siraf; b. a blue painted white low-fired bowl with dots decoration from the Huangye kilns, 756-840 CE

(C) A. BRITISH MUSEUM, NO.2007,6001.5010; B. HENAN CULTURAL RELICS AND ARCHAEOLOGY INSTITUTE (2016: PLATE 130)

FIGURE 40

a. Tang blue and white stoneware sherds from Baihe kilns; b. Tang blue and white stoneware sherd from Yangzhou

(C) A. HENAN CULTURAL RELICS AND ARCHAEOLOGY INSTITUTE (2016: PLATE 262); B. HENAN CULTURAL RELICS AND ARCHAEOLOGY INSTITUTE (2016: PLATE 270)
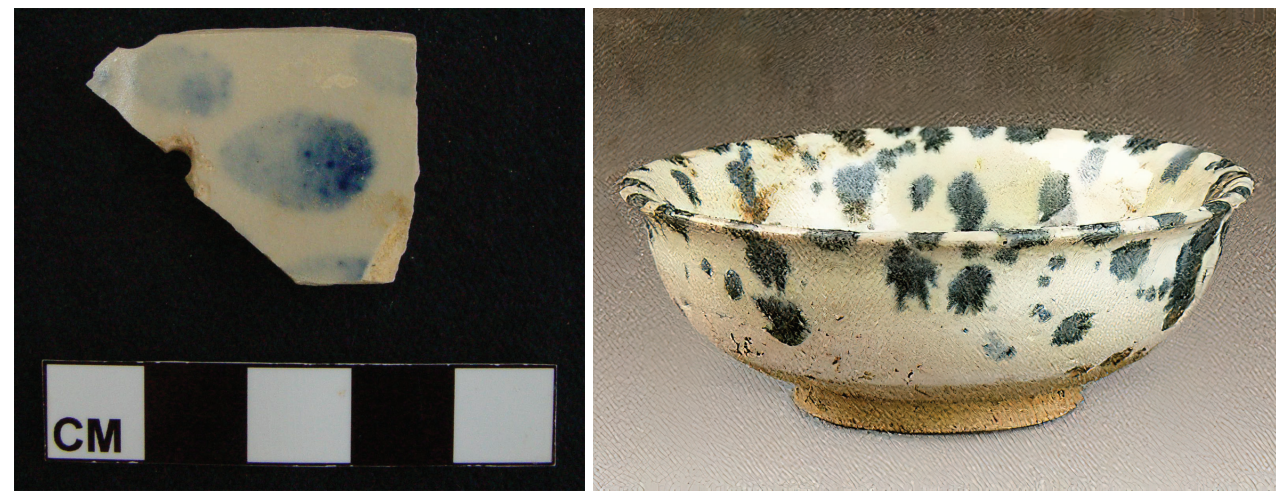

a

b

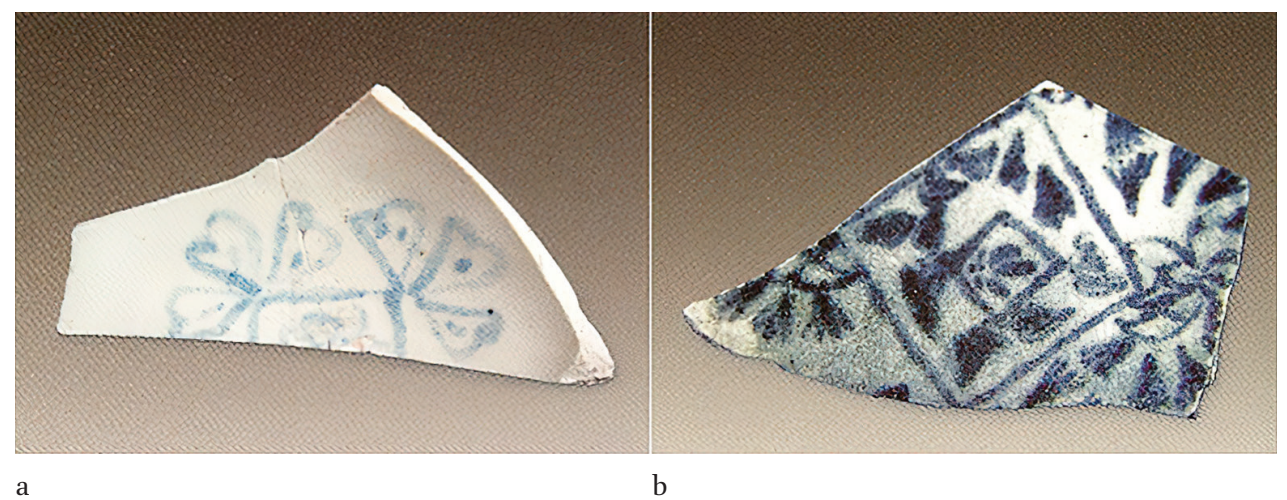

and China across the Indian Ocean. After examining all the known existing Chinese high-fired blue painted white ware, it seems some of them continued using traditional decorative motifs which could be seen on earlier low-fired blue and white earthenware produced in Gongxian kilns, while others adopted a combination of lozenge and vegetal motifs which were unknown to Chinese ceramics before but often seen on Islamic blue painted white ware.

Traditional decorative motifs include dots, dashes or a combination of these two elements, such as on those high-fired blue and white ware found from Huangye kilns and the tripod in the University of Hong Kong Museum. They can be traced back to earlier low-fired Chinese blue and white ware (Fig. 32). Dots and short dashes were often applied to decorate low-fired blue and white ware found from Gongxian kilns. Nigel Wood proposes that the high-fired Gongxian blue and white ware with dots and dashes found in Huangye kilns followed the traditional approach of low-fired blue and white ware, which used simplified Sancai patterns, modified from the funerary Sancai repertoire (Wood and Priestman, 2016: 51). Besides, figurative representations and floral motifs on the pagoda-shaped jars found from the tomb also belong to the traditional decorative motif repertoire.

The combination of lozenge and vegetal motifs can be observed on the high-fired blue and white ware found in Baihe kilns, Yangzhou and the Belitung shipwreck (Figs. 40 and 38 ). This decorative pattern was influenced by contemporary Islamic blue painted white ware, as pointed out by several scholars, such as Jessica Hallet, Regina Krahl and Nigel Wood (Wood and Priestman, 2016: 53). The Islamic white ware has cobalt blue paintings in the form of palmettes, garlands, palm trees and Arabic writings (Fig. 41). The Chinese lozenge and palmette patterns seemed to derive from the quatrefoil panels filled with Arabic writing surrounded by leaf fronds (Krahl, 2011: 210). In addition, the lozenge and palmettes have also been applied on Chinese green splashed ware found in 


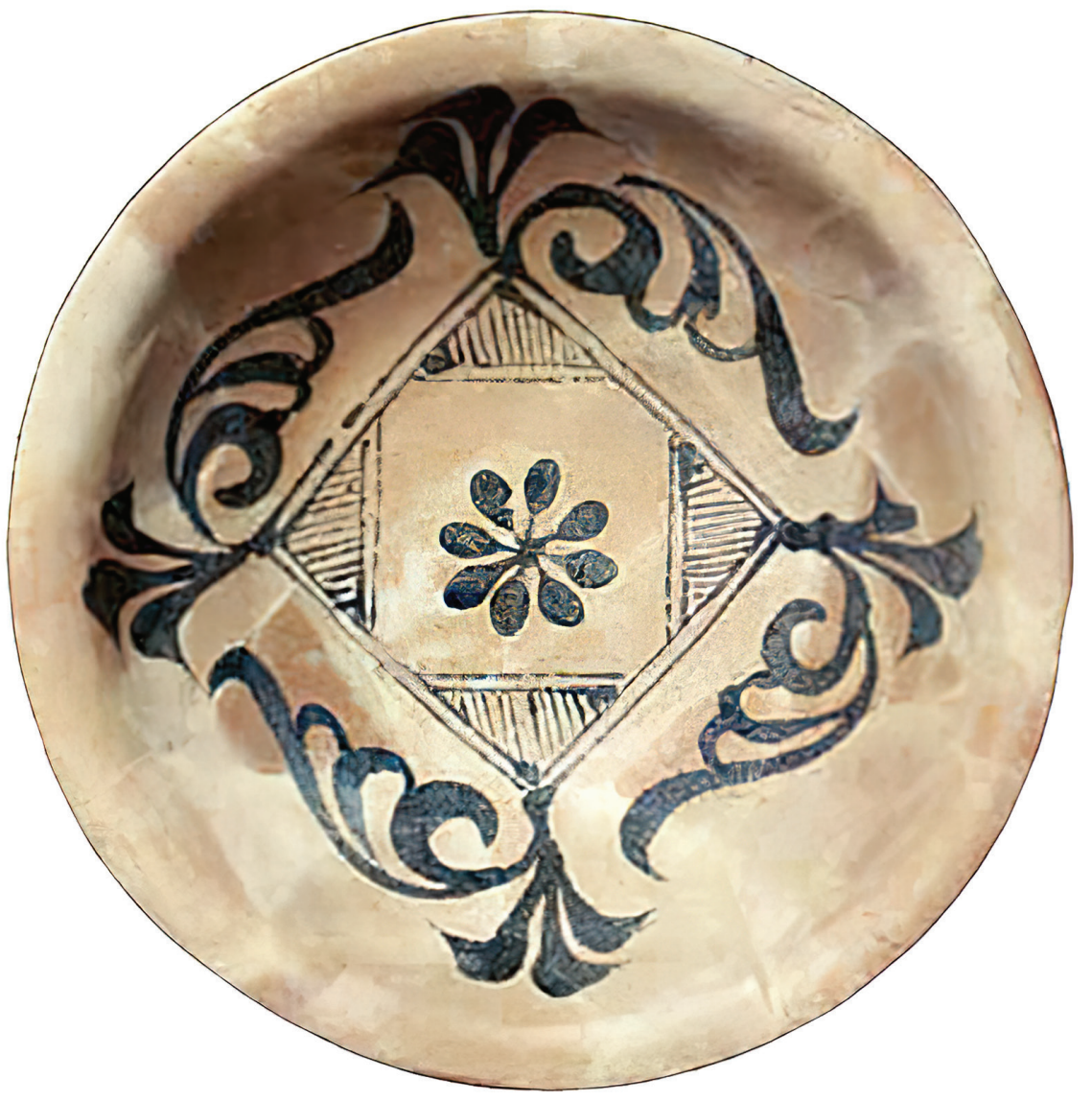

Samarra and in the Belitung shipwreck (Figs. 11a and 42). They were highly likely Baihe kilns' products, as the same decoration has been observed on Baihe kilns' blue painted white ware (Fig. 40a). Baihe kilns might have been responsible for producing certain ceramic wares with "exotic" decorations, which would later be transported overseas to the Islamic lands.

Huangpu kilns (黄堡窑) in Sha'anxi Province also produced unglazed ware with black glazed decorations in lozenge and vegetal patterns (Fig. 43) during the Tang period. These Huangpu kilns' products cannot be dated precisely. Possibly, this "exotic" decorative motif originally from the Islamic lands also exerted influence on more Chinese kilns.

On the other hand, some scholars also propose the possible influence of Tang blue and white ware on the Islamic Samarra Horizon wares. Wood and Priestman point out the possible impact of Tang low-fired blue and white ware with dots decoration on early Samarra Horizon wares, one example of which has identical dots decoration, though not in the same blue colour (Fig. 44) (Wood and Priestman, 2016: 55). Despite the differences in decorative motifs and firing temperatures, Gongxian kilns used the same ironcobalt ore without zinc and higher in the cobalt content for both their early low-fired blue painted white ware and the later two groups of high-fired blue painted ware (Wood and Priestman, 2016: 56).

In conclusion, Gongxian kilns had already established the production of low-fired white ware with blue paintings at least in the eighth century CE. The high-fired ware was probably first produced around $84 \mathrm{O} \mathrm{CE}$ as evidenced by the excavations of Huangye kilns. Some of the high-fired ware adopted lozenge and vegetal motifs from the Islamic decorative repertoire. Others continued using traditional decorations like dots, dashes and Chinese figural and floral motifs. Therefore, the very first production of blue painted
FIGURE 41

An Islamic white glazed bowl with cobalt blue decorations, Basra, ninth century CE (C) V\&A MUSEUM 
FIGURE 42

Chinese green splashed ware with incised lozenge and vegetal motifs from the Belitung shipwreck (C) PHOTO TAKEN BY THE AUTHOR IN NEW YORK

FIGURE 43

Huangpu unglazed ware with black glazed floral and geometric motifs from the Tang period (C) INSTITUTE OF ARCHAEOLOGY, SHA'ANXI PROVINCE (1992: 350, 408)
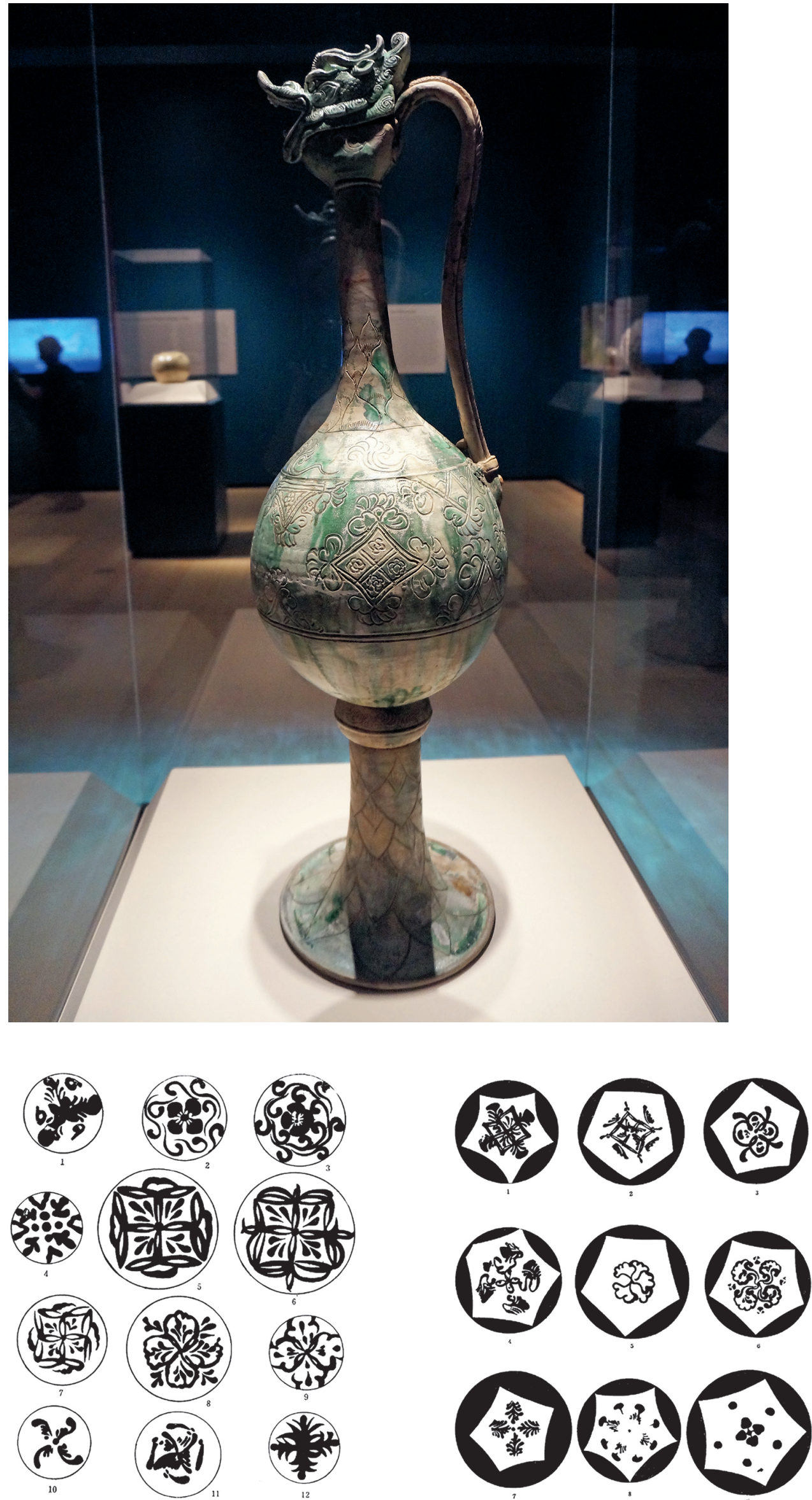
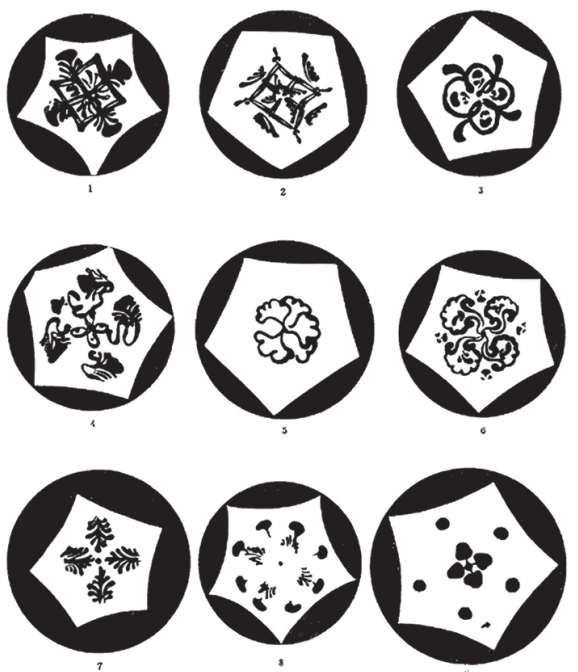


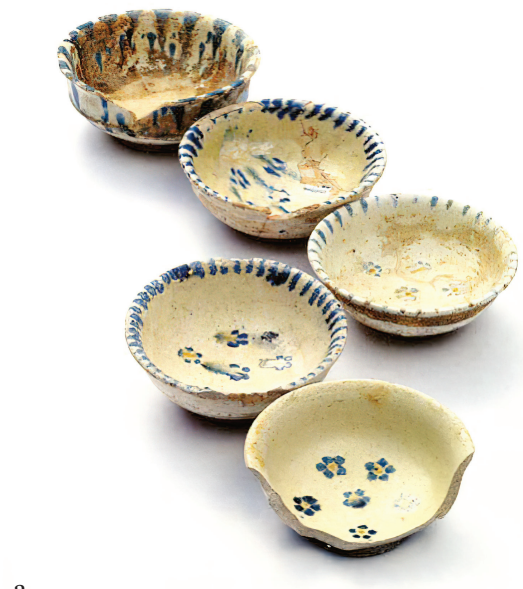

a

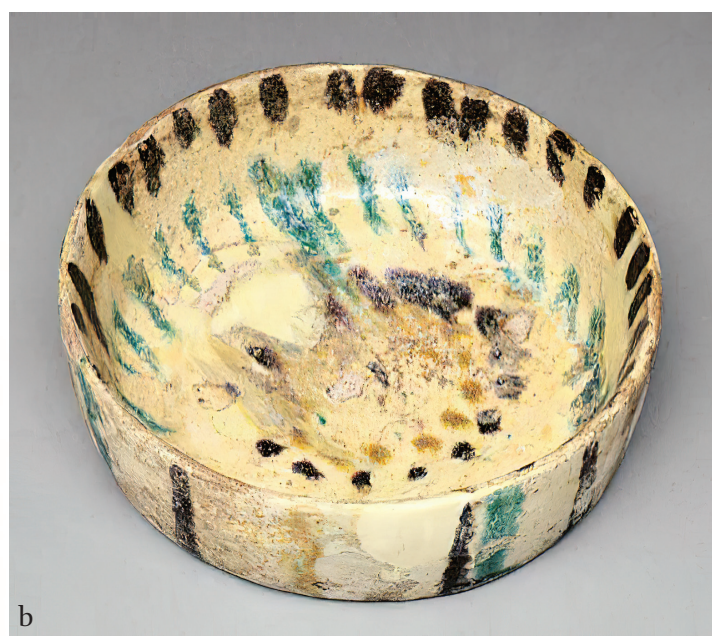

white ware was developed by Chinese potters instead of being inspired by the Samarra Horizon Islamic blue painted white ware. However, due to the scarcity of Chinese blue painted white ware found in the Islamic lands, it is still early to conclude with a Chinese influence on the beginning of the production of Islamic blue and white ware in the ninth century CE. In the ninth century, perhaps due to the contact between the Abbasid caliphate and China, Chinese potters in Gongxian kilns started to produce high-fired blue painted white ware by using their own techniques and raw materials. Some of these high-fired ones continued using traditional decorations that Gongxian kilns had used for more than a century. Potters also incorporated "exotic" Islamic decorative patterns to their ceramic products. Blue painted white ware bearing "exotic" decorations was sent from Gongxian kilns via Yangzhou port over the Indian Ocean to Siraf. Meanwhile, some scholars also propose the possibility that some traditional decorative motifs on Chinese low-fired and high-fired blue painted white ware became known to Islamic potters who incorporated these Chinese motifs to their own ceramics. In short, based on the current available materials and studies, there is no clear Chinese influence on any Samarra Horizon blue painted white ware, and therefore no reason to see a Chinese derivation for this type of decoration.

Three fragments of yellow glazed ware with green splashes and one fragment of white ware with yellow and green splashes were found in Siraf (Figs. 45a and 46). Similar
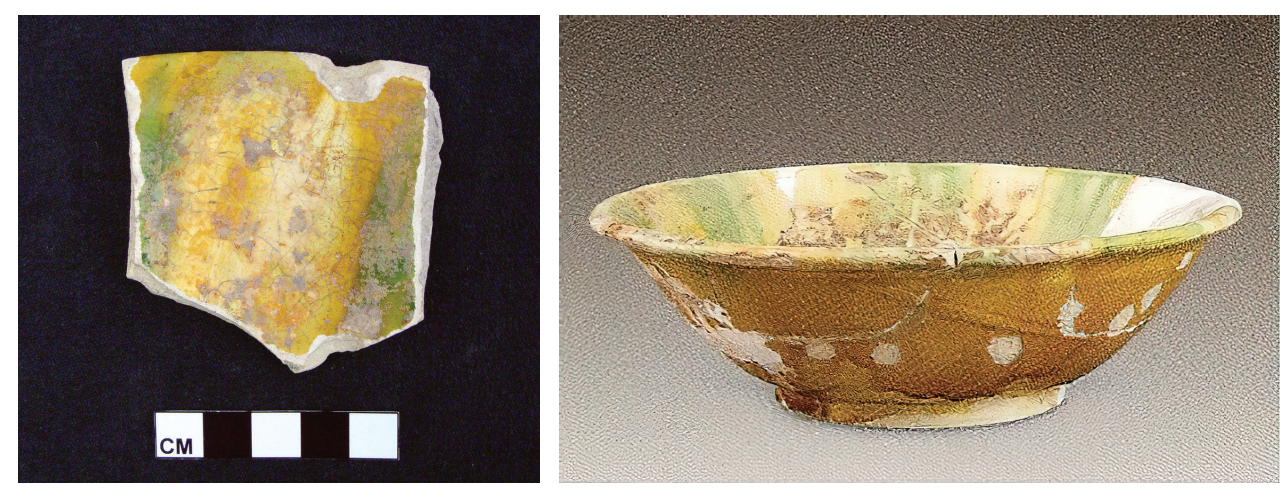

a

$\mathrm{b}$
FIGURE 44

a. Low-fired white glazed ware with blue and/or yellow paintings from Huangye kilns; b. an Islamic bowl with brown and green dots from Iraq or Syria, eighth to ninth centuries CE (Wood and Priestman, 2016: 55)

(C) A. HENAN CULTURAL RELiCS AND ARCHAEOLOGY INSTITUTE (2005: 141); B. AL-SABAH COLLECTION, DAR AL-ATHAR AL-ISLAMIYYAH, KUWAIT
FIGURE 45

a. A fragment of Chinese ware with green and yellow splashes from Siraf; b. a bowl with green and yellow splashes, found from the Huangye kilns, around $841-907 \mathrm{CE}$

(C) A. BRITISH MUSEUM, NO.2007,6001.6734; B. HENAN CULTURAL RELICS AND ARCHAEOLOGY INSTITUTE (2016: PLATE 192) 
FIGURE 46

A fragment of Chinese yellow glazed ware with green splashes from Siraf

(C) BRITISH MUSEUM, NO.2007,6001.6733

\section{FIGURE 47}

A brownish yellow glazed lid with green splashes from the Huangye kilns, 684-756 CE

(C) HENAN CULTURAL RELICS AND ARCHAEOLOGY INSTITUTE (2016: PLATE 68)
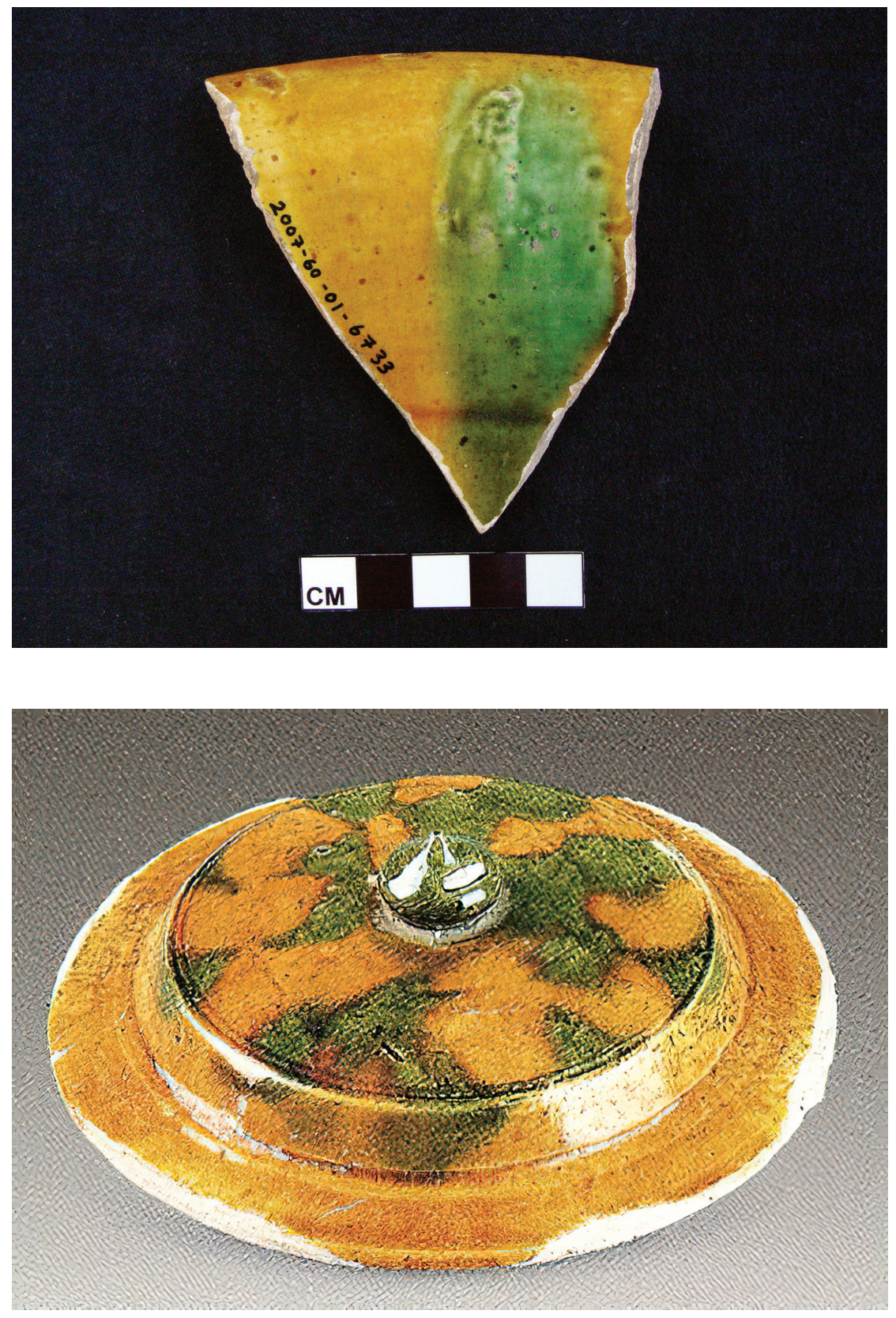

ones have been found in Gongxian kilns. The earliest example from Gongxian kilns is a brownish yellow glazed lid with green splashes dating to the period of $684-756 \mathrm{CE}$ (Fig. 47). Other examples came from the period of around 841-907 CE: a yellow glazed dish with five green dots on the rim and in middle, a yellow glazed bowl with possibly four green patches (Fig. 48) and a bowl with green and yellow stripes (Fig. 45b) identical to the one found in Siraf.

There are two almost intact Islamic yellow glazed vessels with green splashes found in Samarra (Fig. 49): a jar with green dots on the shoulder and a cup with white glaze, yellow dots and green splashes beneath the yellow dots. Even though the Chinese brownish yellow glazed lid with green splashes predates the rest, its brownish glaze colour is different from the later yellow glaze and the Islamic yellow glaze. It is more likely that Chinese yellow glazed ware with green splashes appeared almost contemporary to the two Samarra yellow glazed ceramics, and perhaps no earlier than the ninth century $\mathrm{CE}$. 

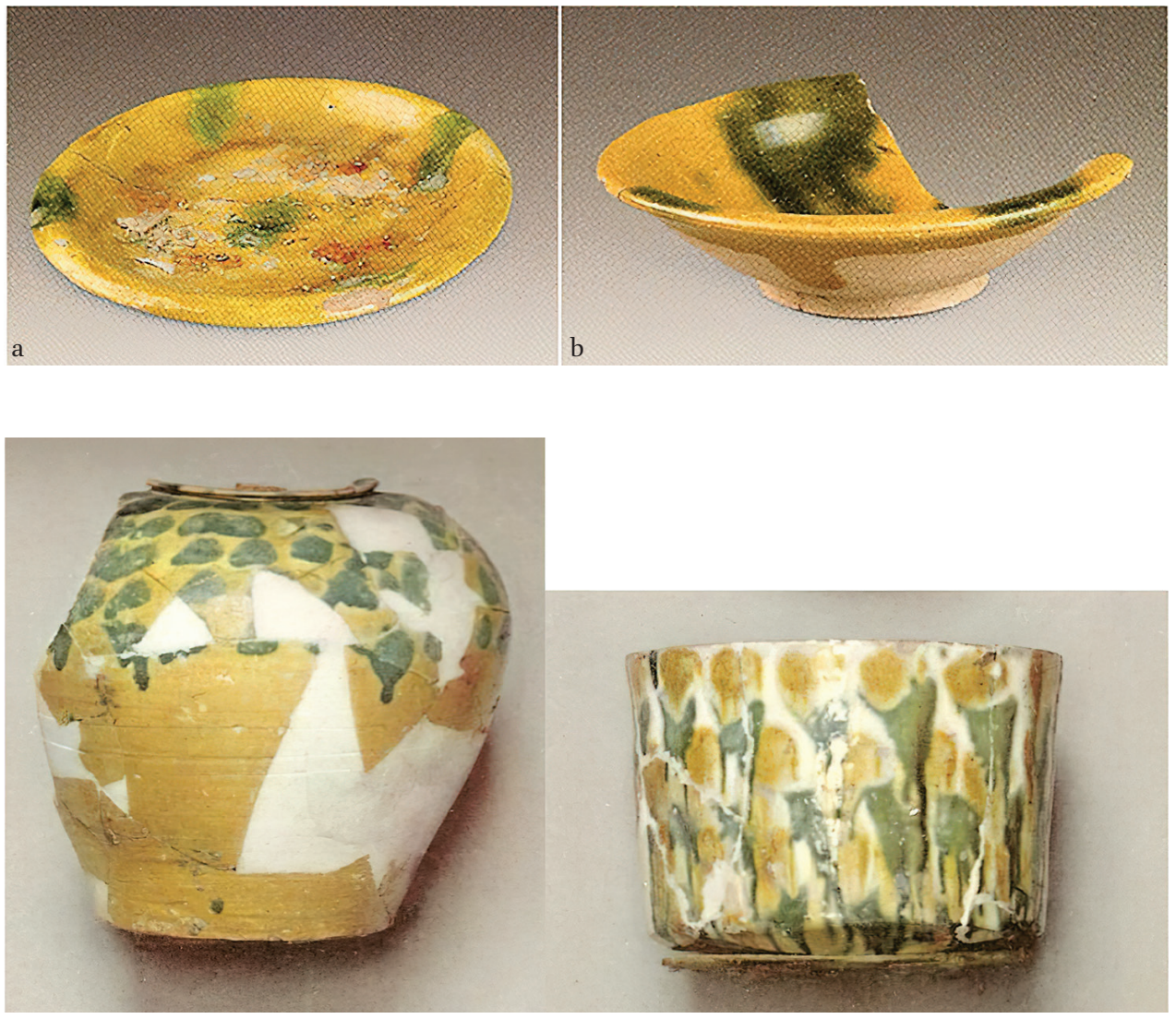

The Islamic lands seem to have a longer tradition than China of producing yellow glazed ware as mentioned in the previous section on the yellow glazed ceramics produced in mid-eighth-century Syria (Fig. 9). China, despite its longer tradition of producing Sancai ware, only started the yellow glazed green splashed ware at some point in the early ninth century CE on a small scale. The time coincided with the contact between China and the Abbasid caliphate over the Indian Ocean in the early ninth century. Therefore, presumably the beginning of the production of Chinese yellow glazed ware with green splashes may have been influenced by the yellow glaze production in the Islamic lands.

\section{White Ware with Green and Brown Streaks}

The use of brown and green streaks converging into the bottom middle of the vessel is shared by both Changsha ware (Fig. 50) and some Islamic splashed ware, such as this one found in Nishapur (Fig. 51b). Scholars used to focus on the possible influence of classic Tang Sancai ware on contemporary Islamic splashed ware; not much attention has been given to Changsha ware which was also influenced by classic Tang Sancai ware. Nigel Wood points out the importance of Changsha ware in understanding the connections between Chinese wares and Islamic splashed ware (Wood et al., 2009: 154-80). Qin Dashu has also paid attention to Changsha ware. During his examination of ceramic finds from Fustat in Cairo, he believed that Changsha ware, instead of classic Tang Sancai ware, had inspired Egyptian potters in producing Fayyumi wares (Qin Dashu, 1995: 83). ${ }^{7}$ However, this type of Changsha ware has not been found yet in any archaeological site in the Islamic Middle East. Therefore, the possible connection and influence is still difficult to prove now.
FIGURE 48

a. A yellow glazed dish with green splashes; b. a yellow glazed bowl with green patches, from the Huangye kilns, 841-907 CE (C) HENAN CULTURAL RELICS AND ARCHAEOLOGY INSTITUTE (2016: PLATE 193)

\section{FIGURE 49}

An Islamic yellow glazed jar with green splashes and an Islamic white glazed cup with yellow dots and green splashes found in Samarra

(c) SARRE (1925: NOS. 229 AND 227) 
FIGURE 50

A Changsha white glazed bowl with green and brown streaks (C) HUNAN MUSEUM
FIGURE 51

a. A dish lamp fragment in opaque white glaze with turquoise blue and brown splashes, Siraf, mid-ninth to tenth centuries CE; b. a polychrome slip painted bowl under monochrome glaze, eighth to ninth centuries $\mathrm{CE}$, Nishapur (C) A. BRITISH MUSEUM, NO. 2007,6001.8030; B. METROPOLITAN MUSEUM OF ART, NO. 39.40.31
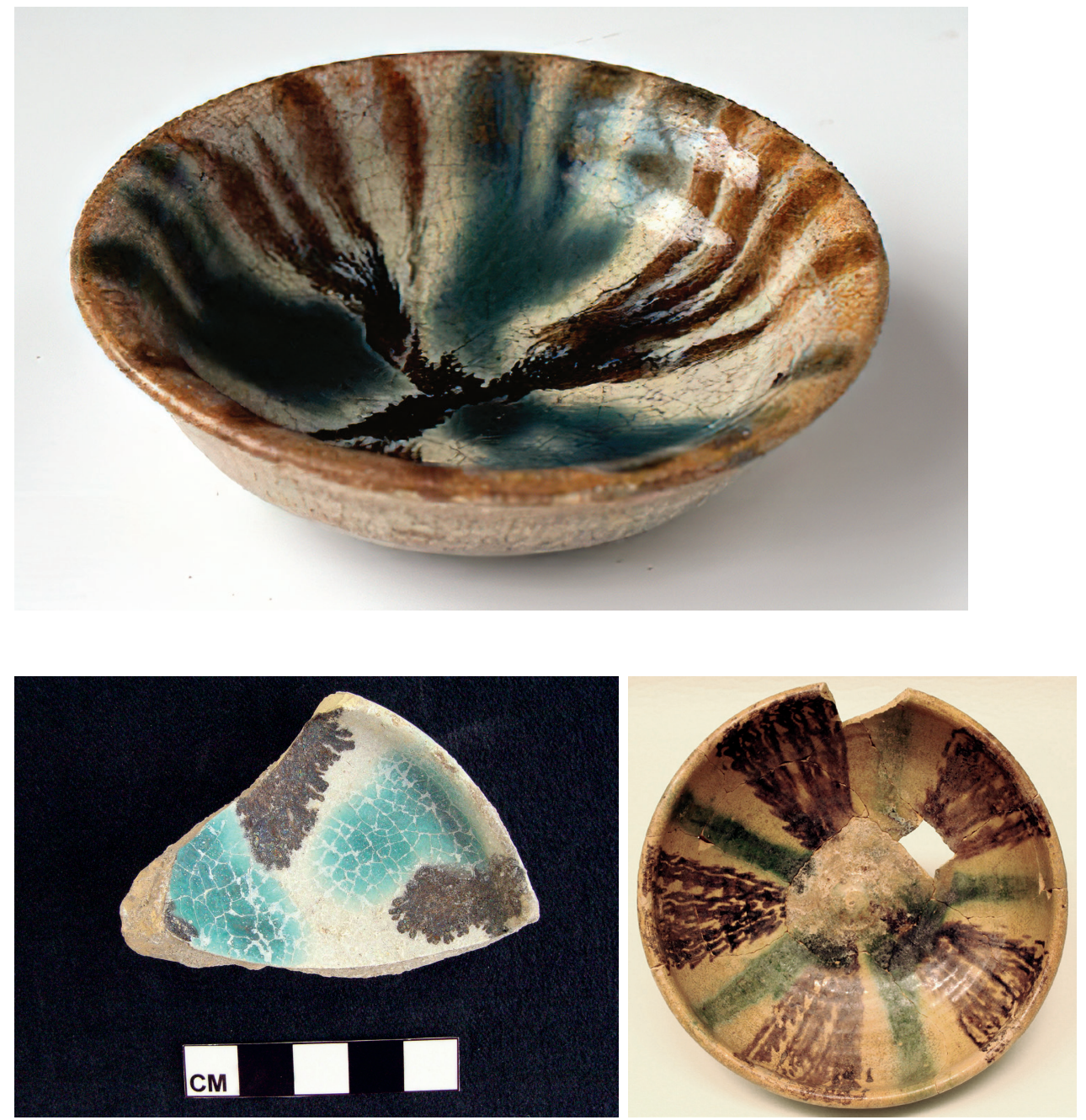

b

White ware with blue and green paintings is a type of Samarra Horizon glazed ceramics. A white glazed ewer with blue and green paintings found in Susa now at the Louvre Museum has been attributed to China dating to the tenth and eleventh centuries CE possibly based on a very early speculation which lacks verification. Nigel Wood explains that this tripod ewer is more likely to be an Islamic tin glazed ware, for its shape is very close to Islamic metalwork and the white glaze is too thick and opaque for Chinese Gongxian wares (Fig. 52). The author agrees with this opinion as such a vessel shape and thick opaque white glaze is not typical to Chinese wares during the Tang period. A fragment of white glazed bowl with green, blue and brownish yellow paintings (Fig. 53a) was found in Huangye kilns dating to around 841-907 CE. However, the leafy twig motif is more often seen on early Islamic glazed ceramics (Fig. 53b). It still remains to be seen whether this ninth-century Chinese bowl was, to some degree, influenced by contemporary Islamic wares. 


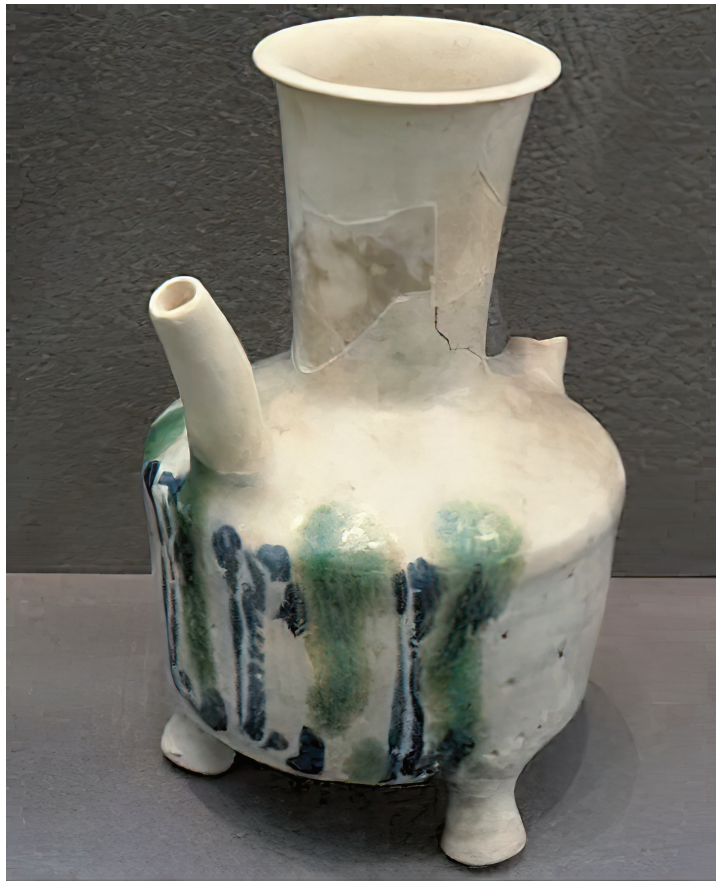

a

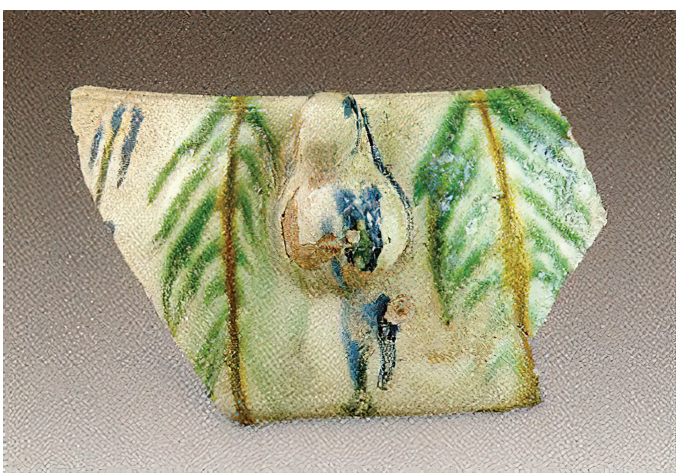

a

b

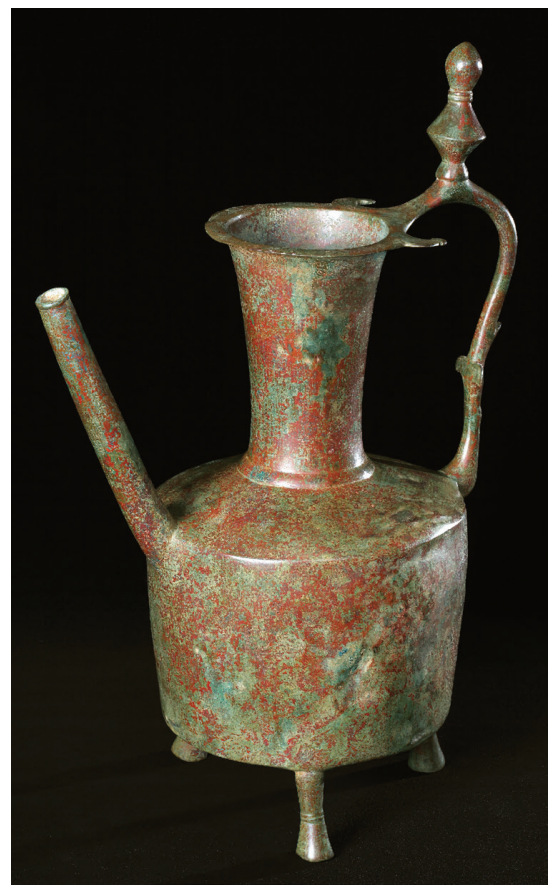

b

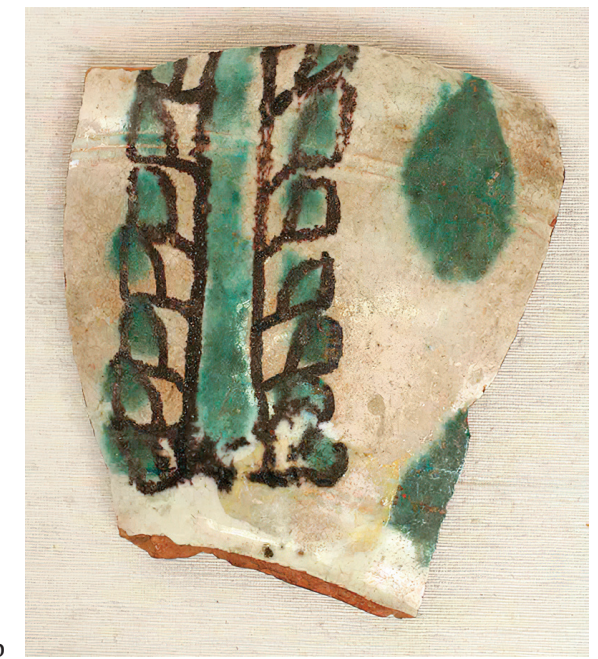

Monochrome Glazed Ware with Moulded Relief Decoration

Both China and the Abbasid caliphate produced monochrome green glazed ware with moulded relief decoration. This type of ware has not been paid much attention before. Islamic monochrome glazed ware with moulded relief decoration is covered with either green or yellow glaze (Figs. 54 and 55). It can be argued that the origin of this technique lies in the Romano-Byzantine Mediterranean world where ceramics imitating metalworks were made. Mason suggests a date between $75^{\circ}$ and $900 \mathrm{CE}$ for the early Islamic moulded monochrome glazed ware (Mason, 2004: 31). Sarre named the yellow monochrome glazed moulded ware as monochrome lustre ware, which is not quite precise.

Chinese monochrome green glazed moulded ware has been discussed in the previous section of Siraf. Xing, Gongxian and Changsha kilns all have produced this type of

\section{FIGURE 52}

a. Tripod white glazed ewer with green and blue paintings found in Susa; b. Egyptian bronze ewer, ninth to tenth centuries CE (C) A. Рното TAKEN BY THE AUTHOR AT THE MUSEUM OF LOUVRE; B. DAVID COLLECTION, DENMARK, INV. NO. 41/2001

FIGURE 53

a. A white glazed bowl fragment with brownish yellow, green and blue decorations, from Huangye kilns; b. a jar fragment of opaque white glaze with blue and brown paintings, ninth century CE, Nishapur

(c) A. HENAN CULTURAL RELICS AND ARCHAEOLOGY INSTITUTE (2016: PLATE 201); B. METROPOLITAN MUSEUM OF ART, 40.170.425 
FIGURE 54

Islamic monochrome yellow glazed sherds with moulded decorations from Samarra (C) PHOTO TAKEN BY THE AUTHOR AT THE VICTORIA AND ALBERT MUSEUM

FIGURE 55

a. and b. Islamic monochrome green lead glazed dishes, eighth to ninth centuries $\mathrm{CE}$

(C) PHOTOS TAKEN BY THE AUTHOR AT THE MUSEUM OF LOUVRE
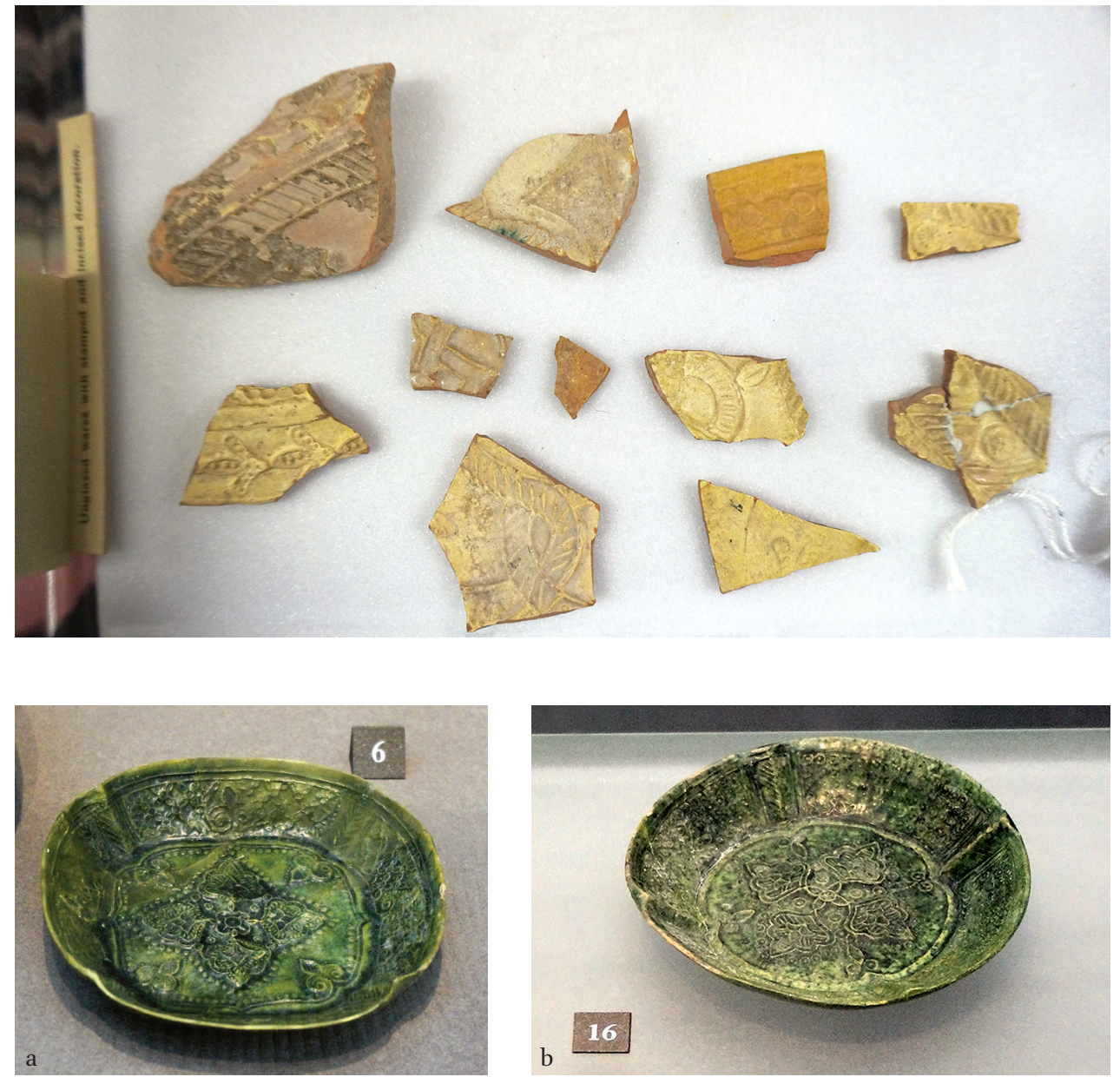

ware in a monochrome green, green splashed white glaze or green and brown glaze. They have been found in Siraf and Samarra. There seems to be no precedent of this type of ware in China before the Tang dynasty. The thin walls and moulded relief decorations reveal a prototype of metalworks from Central Asia, which were popular among the elite in China then.

Even though this type of Chinese ware has been found in Islamic sites, it might not be true to indicate a Chinese influence on Islamic monochrome glazed moulded ware or vice versa. The Islamic ones were produced earlier than the arrival of Chinese ceramics. Their visual similarities including the metalwork shapes, the moulded relief decorations, the thin walls and monochrome green glaze all indicate their shared prototype metalworks in Central Asia and the Middle East. Both Islamic and Chinese potters were imitating metalworks that were known to them and popular at their times. This type of ware was not produced in a great quantity during the Tang period; the quantity found in the Islamic lands is not great either.

\section{Technical Factors}

It is also important to consider technical factors which may contribute to the visual effects of the flowing splashes and streaks. The lead glaze used on Chinese Sancai ware is rather fusible which tends to spread in firing (Wood and Priestman, 2016: 51). The mottled effect on Sancai ware was perhaps not intended in the beginning but caused 

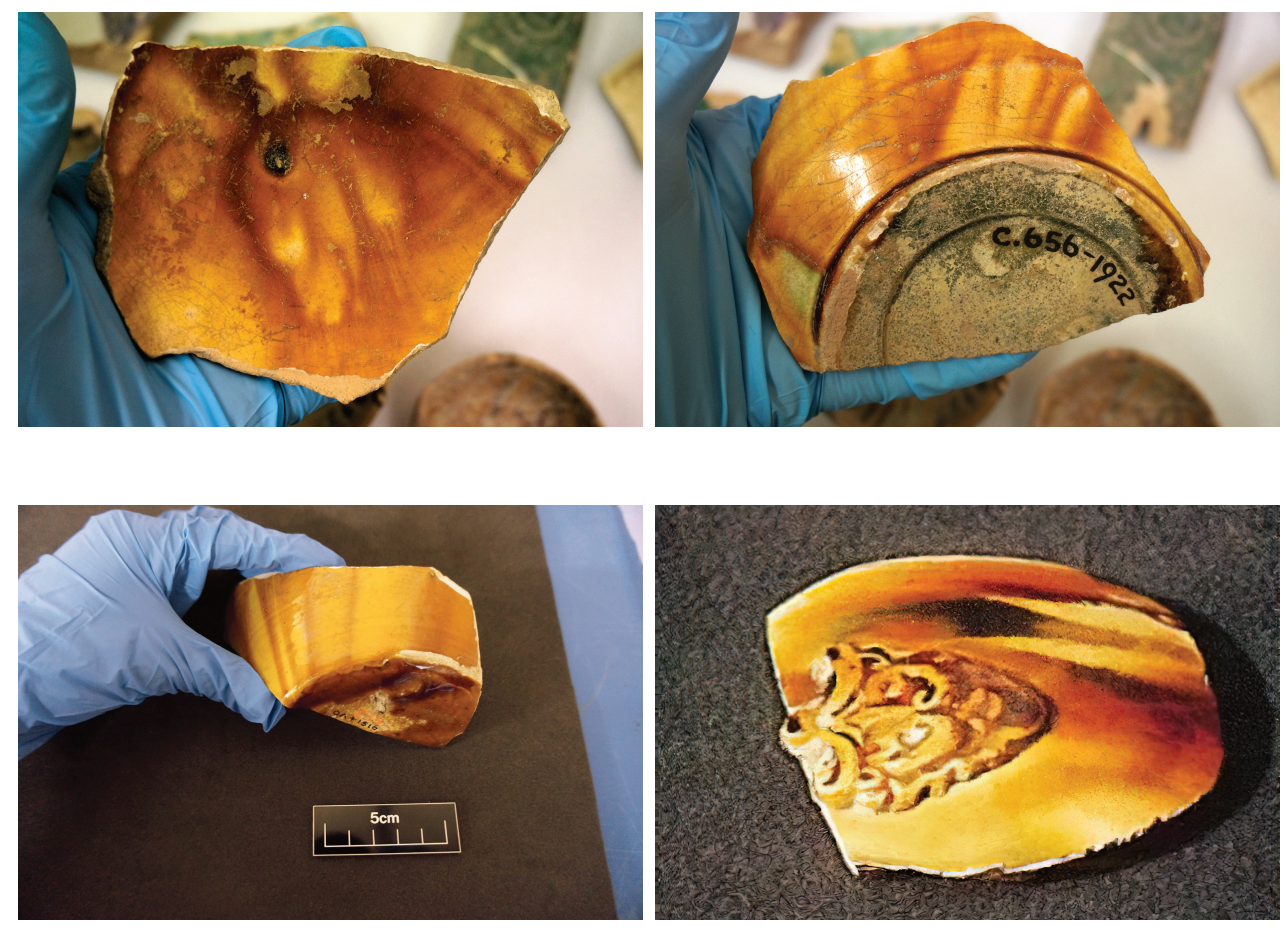

a

$\mathrm{b}$

by accident. When Chinese white ware was introduced to the Abbasid lands, it was imitated quickly by local potters. Islamic potters were tempted to add decorations on the plain white surface. Various oxide pigments, usually copper green or turquoise, iron black and manganese purple, were splashed onto the opaque white glaze (Mason, 2004: 29). Another type of Islamic splashed ware used lead glaze over a white slip splashed with oxide pigments, the glaze of which comprised about 5 o per cent lead oxide. Some bear incised decorations through the slip, which are named as sgraffiato ware (Mason, 2004: 31, 36). The lead glaze used on this type of Islamic splashed ware also tends to fuse and flow into each other during firing, therefore generating the similar mottled effect (Figs. 56 and 57). Oliver Watson contributes the similarities between the mottled Chinese classic Sancai ware and Islamic white slip transparent glazed splashed ware to some "technical convergence," that potters in China and the Islamic lands happened to both use lead glaze on some ceramic vessels (Watson, 2004: 47). It is too early to rule out any influence from Chinese wares on contemporary Islamic splashed ware. But we cannot rule out either the possibility that some of the visual similarities were caused by the use of the fusible lead glaze and multi-colour oxide pigments.

\section{1}

\section{Conclusion}

There are only sixteen sites in the Islamic Middle East dating to the eighth to tenth centuries CE with Chinese splashed ware and blue painted ware finds. The amount of these two types of Chinese wares found in these sites is scarce. There is no firm evidence for any classic Tang Sancai ware found in the Abbasid lands. Therefore, the sweeping assumption that Chinese classic Tang Sancai ware was exported to the Abbasid caliphate and imitated by Islamic splashed glazed ware apparently lacks solid evidence unless new discoveries prove otherwise. The production of Chinese green splashed ware predates that of the Samarra Horizon Islamic green splashed ware. Islamic green splashed
FIGURE 56

Islamic amber colour splashed bowl fragment from Samarra, around 656-1922 CE, in the Victoria and Albert Museum (C) PHOTO TAKEN BY THE AUTHOR

\section{FIGURE 57}

a. Islamic amber colour splashed bowl fragment from Samarra in the British Museum, OA. 1516; b. a Chinese amber colour splashed bowl fragment (C) A. PHOTO TAKEN BY THE AUTHOR; B. GONGYI MUNICIPAL OFFICE FOR THE PRESERVATION OF ANCIENT MONUMENTS, HENAN PROVINCE (2000: PLATE 54) 
ware may have been influenced by both Chinese green splashed ware and the green splashed yellow glazed ware produced in Syria in the mid-to-late eighth century CE.

Gongxian kilns in China started producing low-fired blue painted white ware at least in the eighth century CE. Therefore, the very first production of blue painted white ware was developed by Chinese potters instead of being inspired by the Samarra Horizon Islamic blue painted white ware. However, due to the scarcity of Chinese blue painted white ware found in Islamic sites, it is still early to conclude with a Chinese influence on the beginning of the production of Islamic blue and white ware in the ninth century $\mathrm{CE}$. In the ninth century, probably due to the contact between the Abbasid caliphate and China, Chinese potters in Gongxian kilns started to produce high-fired blue painted white stoneware by using their own techniques and raw materials. Potters also started to incorporate some "exotic" Islamic decorative patterns to some high-fired blue and white and some green splashed ware.

In addition to the highly debatable green splashed ware and blue painted ware, both the Abbasid caliphate and China produced yellow glazed ware with green splashes, with the former tracing back to the mid-to-late eighth century and the latter to the early ninth century CE. Presumably, the beginning of the production of Chinese yellow glazed ware was influenced by the ceramic production in the Abbasid caliphate, which became known to Chinese potters due to the Indian Ocean maritime exchange in the ninth century. There are also other types of ceramics which China and the Abbasid lands both produced in the ninth century, such as white ware with blue and green paintings and white ware with green and brown streaks. It is important to investigate these two types of ceramics and examine the mutual influence between Chinese ceramic production and Islamic ceramic production.

Finally, there may be more than one explanation for the visual similarities between Chinese and Islamic wares during the eighth and tenth centuries CE. It is necessary to investigate metalworks of Central Asia and Middle East, which may have served as a source of influence on contemporary ceramic productions in both the Abbasid lands and China. Further studies on their glazes and technical factors are essential to enable us to explore the Samarra Horizon through new angles and perspectives. 


\section{Appendix}

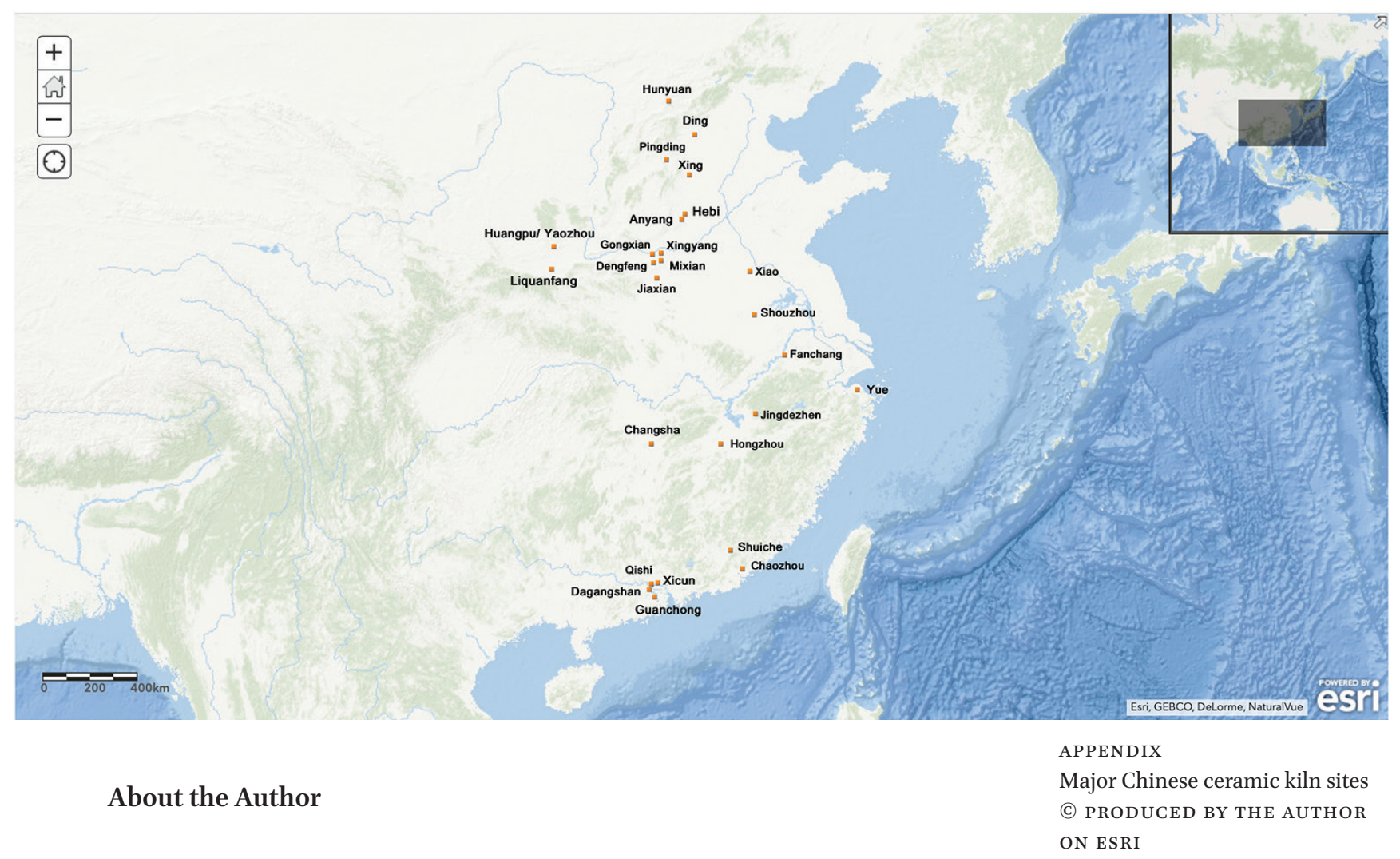

Wen Wen studied Arabic and world history at the Peking University. She completed a DPhil in archaeology at the University of Oxford writing on Chinese ceramics from the Islamic world. She is a researcher in the art and archaeology of the Islamic world, China and the ancient "Silk Road."

\section{Bibliography}

Gongyi Municipal Office for the Preservation of Ancient Monuments, Henan Province [河南省 巩义市文物保护管理所] (2000). Three-Coloured Glazed Pottery Kilns of the Tang Dynasty at Huangye [黄冶唐三彩窑]. Beijing: Science Press.

Gyllensvärd, B. (1973). Recent Finds of Chinese Ceramics at Fostat I. Bulletin Östasiatiska museet. [Offprint.] Stockholm.

Henan Cultural Relics and Archaeology Institute [河南省文物考古研究所] (2005). New Archaeological Discoveries at Huangye kilns [黄治窑考古新发现]. Zhengzhou: Elephant Press.

Henan Cultural Relics and Archaeology Institute [河南省文物考古研究所] (2016). Gongyi Huangye Kilns [巩义黄冶窑]. Beijing: Science Press.

Hobson, R.L. (1932). Chinese Porcelain from Fostat. Burlington Magazine, September, pp. 109-13. Institute of Archaeology, Chinese Academy of Social Sciences [中国社会科学院考古研究所], Nanjing Museum [南京博物馆] and Yangzhou Municipal Institute of Cultural Relics and Archaeology [扬州市文物考古研究所] (2010). Yangzhou City: Archaeological Excavation Report 1987-1998 [扬州城: 1987-1998 年考古发掘报告]. Beijing: Cultural Relics Press.

Institute of Archaeology, Sha'anxi Province [陕西省考古研究所] (1992). Excavation of a Tang Kiln-Site at Huangpu in Tongchuan, Sha'anxi [唐代黄堡窑址]. Beijing: Cultural Relics Press.

Jia Chenghui, Lei Yong, Feng Songlin and Feng Xiangqian [贾成惠, 雷勇, 冯松林, 冯向前] (2007).

Tang Sancai Wares in Xing kilns [浅议邢窑唐三彩]. In: Li Enwei, Zhang Zhizhong and Li Jun 
[李恩玮, 张志忠, 李军], eds., Research on Xing Kilns [邢窑遗址研究], Beijing: Science Press, pp. 491-5.

Krahl, R. (2011). Green Wares of Southern China. In: Shipwreck, Tang Treasures and Monsoon Winds, Washington: Arthur M. Sackler Gallery, Smithsonian Institute; Singapore: National Heritage Board, Singapore Tourism Board, pp. 185-99.

Lane, A. (1947). Early Islamic Pottery. London: Faber and Faber.

Li Zhiyan [李知宴] (1972). Ceramics from the Tomb of Fancui [谈范粹墓出土的瓷器]. Archaeology [考古] 5, pp. 53-5.

Mason, R. (2004). Shine like the Sun: Lustre-Painted and Associated Pottery from the Medieval Middle East. Costa Mesa: Mazda Publishers in association with Royal Ontario Museum.

Medley, M. (1981). T'ang Pottery and Porcelain. London: Faber and Faber.

Mikami, T. (1982). China and Egypt: Fustat. Transactions of the Oriental Ceramic Society, pp. $67-89$.

Northedge, A. (2007). The Historical Topography of Samarra. London: British School of Archaeology in Iraq; Foundation Max van Berchem.

Northedge, A. and Kennet, D. (1994). The Samarra Horizon. In: E. Grube and M. Bayani, eds., Cobalt and Lustre: The First Centuries of Islamic Pottery (Nasser D. Khalili Collection of Islamic Art 9), London: Nour Foundation in association with Azimuth and Oxford University Press, pp. 21-35.

Priestman, S. (2005). Settlement and Ceramics in Southern Iran: An Analysis of the Sasanian and Islamic Periods in the Williamson Collection, PhD Dissertation, Durham University.

Qin Dashu [秦大树] (1995). Chinese Ceramics Found in Fustat, Egypt [埃及福斯塔特遗址中发现 的中国陶瓷].Journal of Maritime History Studies [海交史研究] 1, pp. 79-91.

Rashid, S. (1980). Darb Zubaydah:The Pilgrim Road from Kufa to Mecca. Riyadh: Riyadh University Libraries.

Rougeulle, A. (1991). Les importations de céramiques chinoises dans le golfe arabo-persique (VIII $-\mathrm{X}^{\mathrm{e}}$ siècles). Archéologie Islamique 2, pp. 5-46.

Sarre, F. (1925). Die Keramik von Samarra. Berlin: Dietrich Reimer.

Scanlon, G. and Kubiak, W. (1989). Fusțāț Expedition Final Report Vol: 2. American Research Center in Egypt reports, v. 11. Winona Lake: Published for the American Research Center in Egypt, by Eisenbrauns.

Tadanori, Y. (2013). Chinese Porcelain from Fustat Based on Research from 1998-2001. Transactions of the Oriental Ceramic Society 76, pp. 1-17.

Tampoe, M. (1989). Maritime Trade between China and the West: An Archaeological Study of the Ceramics from Siraf (Persian Gulf), 8th to 15th Centuries A.D. Oxford: BAR.

Watson, O. (1999). Report on the Glazed Ceramics. In: P. Miglus and A. Becker, eds., Die frühislamische Keramik von Tall Aswad (Ar-Raqqa (Series): 1), Mainz am Rhein: P. von Zabern, pp. $81-87$.

Watson, O. (2004). Ceramics from Islamic Lands. London: Thames \& Hudson, in association with the al-Sabah Collection, Dar al-Athar al-Islamiyyah, Kuwait National Museum.

Watson, O. (2014). Revisiting Samarra: The Rise of Islamic Glazed Pottery. In: J. Gonnella, R. Abdellatif and S. Struth, eds., Beiträge zur islamischen Kunst und Archäologie. Bd. 4, Wiesbaden: Reichert, pp. 123-42.

Wen, W. (2018). Chinese Ceramics in the Islamic World from the 8th to 1oth Centuries CE, DPhil Thesis, University of Oxford.

Whitehouse, D. (2009). Siraf: History, Topography and Environment. The British Institute of Persian Studies Archaeological Monographs Series I. Oxford: Oxbow.

Wilkinson, C. (1973). Nishapur: Pottery of the Early Islamic Period. New York: Metropolitan Museum of Art; distributed by New York Graphic Society, Greenwich, Conn.

Wood, N., Doherty, C. and Owen, M. (20o9). A Technological Study of Iraqi Copies of Chinese Changsha and Chinese Sancai Wares Found at Samarra. International Symposium on Ancient Ceramics 'og. Shanghai: Shanghai Scientific and Technological Literature Press, pp. 154-80. 
Wood, N. and Tite, M. (2009). Blue and White - the Early Years: Tang China and Abbasid Iraq Compared. In: S. Pierson, ed., Transfer: The Influence of China on World Ceramics (Colloquies on Art and Archaeology in Asia, No. 24), London: University of London, Percival David Foundation of Chinese Art, School of Oriental and African Studies, pp. 21-45.

Wood, N. and Priestman, S. (2016). New Light on Chinese Tang Dynasty and Iraqi Blue and White in the Ninth Century: The Material from Siraf, Iran. Bulletin of Chinese Ceramic Art and Archaeology 1/7, pp. 47-6o.

Zhao Qinggang and Zhang Zhizhong [赵庆钢, 张志忠] (2007). Xing Kiln in Its Millennium [千年 邢窑]. Beijing: Cultural Relics Press.

\section{Notes}

1 These sites are Rayin, B10, D10, T. Cheraghabad, Neran, Ziarat, Rishahr and Gharibou.

2 See details of the green splashed white ware sherds identified by Tadanori in the discussions of Fustat and Fig. 6.

3 The author will expand the discussion on the Belitung shipwreck, the date when it was wrecked and its final destination in another forthcoming paper.

4 See British Museum Siraf Project online database: www.britishmuseum.org/collection/term/x21623.

5 See the discussion on Xing kilns' moulded relief decoration in the section of Samarra ceramic finds.

6 Wood and Tite also identified the origin of decorating white ware with cobalt blue in Gongxian kilns around the eighth century CE (Wood and Tite, 2009: 21).

7 The production of Fayyumi ware is an ongoing debate. It is still an assumption that Fayyumi was inspired by Changsha ware imports. 